\title{
Foreign banks, financial crises and macroeconomic fluctuations ${ }^{1}$
}

\section{Zeynep Önder and Süheyla Özyıldırım}

Faculty of Business Administrations, Bilkent University, Ankara, Turkey.

E-mail: zonder@bilkent.edu.tr; suheyla@ bilkent.edu.tr

\section{Abstract}

Understanding the implications of increased foreign bank presence is especially compelling in periods of financial crisis. In this paper, we explore this issue by examining the relationship between the involvement of foreign banks in the banking systems and the volatility of key macroeconomic variables in normal and crisis periods. Using a sample of 20 Emerging European countries from 1998 to 2013, we find that an increase in the assets of foreign banks in the banking system reduces output and consumption growth volatility in general but does not significantly affect the volatility of investments. However, these banks were found to play a significant role in increasing output, consumption and investment volatility in 2009. Our findings suggest that foreign banks' harmful impact during the global crisis was only temporary and that they seem to help Emerging European countries stabilize macroeconomic volatility in normal times and after the global crisis.

JEL classifications: G21, E32, F43.

Keywords: Foreign banks, macroeconomic volatility, crisis, Emerging Europe.

Received: January 27, 2014; Acceptance: January 18, 2016

1 This study is supported by TUBITAK (The Scientific and Technological Research Council of Turkey) with project number 110K369. We thank TUBITAK for this financial support. We also thank Selçuk Caner, Ali Kutan, Andy Lardon, Isabel Schnabel (The Editor) and two anonymous referees for their helpful comments. 


\section{Introduction}

The 2008/2009 global financial crisis reignited the debate on the stabilizing force of foreign banks. These banks were accused of playing a significant role in transmitting the crisis to emerging market economies (Cetorelli and Goldberg, 2011). Although several countries with significant foreign bank presence have indeed experienced periodic collapses in growth rates, as well as financial crises resulting in substantial macroeconomic and social costs (Agénor, 2013), foreign banks have many positive effects, such as promoting banking sector efficiency, providing greater access to resources from abroad and improving lending practices in the host countries. Developing countries, with their relatively low levels of capital and inherently greater volatility, seem to gain the most from the presence of foreign banks and several other forms of financial integration (Agénor, 2003; Prasad et al., 2007).

Over the past decade, many emerging and developing economies have attracted strong capital inflows and allowed active participation of foreign banks. Until the recent global financial turmoil, these countries seemed to be in a good position to reap the benefits of such developments. However, the crisis reshaped the debate on whether foreign banks are a destabilizing force, increasing volatility rather than promoting growth. On the one hand, they are expected to improve growth and reduce volatility by providing loans, even during domestic or local crises. On the other hand, they may withdraw their resources during downturns or when they face problems in their home countries, causing more volatility in emerging economies. In this paper, we examine the association between foreign bank presence and volatility in real GDP growth rate and its components, mainly consumption and investment, for a sample of Emerging European countries over the period 1998-2013. ${ }^{2}$ We also analyze how this relationship changed during the 2008/2009 global crisis. In the analysis, foreign bank presence is measured with the share of these banks in the total assets of the banking system of each country.

In the literature, although several studies analyze the role of foreign banks in financial stability (see, e.g., Barth et al., 2006; De Haas and van Lelyveld, 2006, 2014), the effects of these banks on macroeconomic fluctuations have not been much examined. Among the few studies that investigate this relationship, Morgan et al. (2004) find that macroeconomic volatility, defined as fluctuations in employment growth, fell significantly as banks became more integrated with out-of-state banks in the United States. Such banks can be considered 'foreign' because most States forbade entry by banks from other States during the sample period of 1976-1994. In another study, Morgan and Strahan (2004) present evidence that foreign banks amplify volatilities of investment spending growth in a sample of Latin American countries.

2 As in Berglöf et al. (2010), we define Emerging Europe broadly. The countries analyzed in this study are Albania, Belarus, Bosnia and Herzegovina, Bulgaria, Croatia, Czech Republic, Estonia, Hungary, Latvia, Lithuania, Macedonia, Moldova, Poland, Romania, the Russian Federation, Serbia, Slovakia Republic, Slovenia, Turkey and Ukraine. 
However, when they analyze a broader sample of countries, they observe zero or a positive association between the volatility of a country's real GDP or investment growth and the share of assets owned by foreign banks. Although some Latin American countries experienced domestic crises during the sample period of 1990-1997, there was no global financial shock in this period.

Emerging European countries provide an ideal setting for examining the relationship between macroeconomic volatility and foreign banks in the aftermath of the global crisis. Of all regions, Emerging Europe has been most affected by the crisis and foreign-owned banks have remained dominating forces in the region. Since the early 1990s, the less-developed financial systems of these countries offered significant growth opportunities and a high return on direct investment, with foreign banks holding 63.57 percent of total banking assets by 2013, up from 24.03 percent in 1998 (see Table A1). Before the 2008/2009 global crisis began, the flood of cheap credit encouraged overborrowing, helped inflate asset price bubbles and increased possible vulnerabilities in the region (see Allen et al., 2011). Emerging Europe was thus badly affected by the global economic downturn, with annual real GDP falling by 6.08 percent in 2009, the greatest decrease worldwide. ${ }^{3}$ Furthermore, several studies report that foreign banks reduced their lending more than domestic banks during the crisis period, especially in this region (Cull and Martínez Pería, 2013; De Haas and van Lelyveld, 2014). On examining the effect of financial deepening generated by foreign banks among Emerging European countries, we try to fill the gap in the literature on how these banks may affect macroeconomic volatility in a global credit crunch.

Analyzing the role of foreign banks in 20 Emerging European countries during normal and global crisis periods, we find that an increase in the assets of foreign banks in the banking system reduces output and consumption growth volatilities in general but does not significantly affect the volatility of investments. During the crisis years of 2008/2009, foreign banks were found to increase macroeconomic volatility only in 2009. However, this amplifying effect seemed to be temporary. Our empirical findings are robust when we measure foreign bank presence with the foreign bank assets-to-GDP ratio and when we measure volatility with squared residuals. We find similar results when we control for foreign bank presence in the first-stage estimations of growth rates. Moreover, the results are robust when we exclude countries that participated in the Vienna Initiative, which ensured that parent banks maintained their exposures and recapitalized their subsidiaries during the initial stages of the crisis.

The paper is organized as follows: Section 2 reviews the literature on macroeconomic growth and volatility and foreign banks. Section 3 presents the empirical model and the data. Section 4 reports the results and the outcomes of several robustness checks. Section 5 concludes the paper.

3 According to the World Development Indicator statistics, the greatest decline in 2009 was -17.95 percent in Latvia; followed by Ukraine, -14.8 percent; Lithuania, -14.74 percent and Estonia, -14.73 percent.

(c) 2016 The Authors

Economics of Transition (c) 2016 The European Bank for Reconstruction and Development 


\section{Literature review}

Financial sector foreign direct investment is a relatively new phenomenon, and typically takes the form of banks in industrialized countries establishing branches and facilities in developing countries (Goldberg, 2007). Following the fall of the Soviet Union, global banks began to enter Eastern Europe. The increase in foreign bank presence is arguably one of the most striking developments in the banking systems of transition economies (Bonin and Schnabel, 2011; Buch, 1997; Naaborg et al., 2004). As emphasized in Levine (1996), foreign banks may promote financial development directly by providing high-quality banking services, and indirectly by affecting domestic banks and regulators, spurring them to improve quality, cut costs and/or enhance economic efficiency. ${ }^{4}$ These banks also accelerate the process of harmonizing regulatory and supervisory procedures and standards (Crystal et al., 2002). Moreover, they are found to benefit firms by stimulating growth in their sales and assets (Giannetti and Ongena, 2009) and by lowering their financing obstacles (Clarke et al., 2006).

A number of papers show that foreign institutions strengthen financial stability in emerging markets by improving the solvency and liquidity of the host countries' banking systems (see, e.g., Caprio and Honohan, 2002). Banking sector solvency improves because foreign banks are better capitalized than their domestic counterparts. Moreover, foreign banks mitigate the risk of sudden stops and capital flow reversals because parent banks will provide the needed international liquidity in crisis periods to safeguard their investments in the respective countries. For example, Detragiache and Gupta (2006) find that foreign banks did not abandon the local market during the 1997/1998 crisis in Malaysia. Similarly, Goldberg et al. (2000) present evidence that lending by foreign banks in Argentina and Mexico grew faster than lending by domestic banks during the 1994/1995 crisis. Althammer and Haselmann (2011) theoretically show that foreign banks do not reduce their lending in emerging markets experiencing banking crises because they have better screening and monitoring mechanisms than domestic banks. Furthermore, Grittersova (2014) shows that a high level of foreign bank ownership is positively associated with the perceived credit quality of host countries' sovereign debt, especially in transition and developing countries that face difficulties raising money in financial markets.

In contrast to these findings, there is evidence that foreign banks might impair financial stability. For example, Peek and Rosengren (2000) argue that foreign bank penetration may weaken the position of the domestic banking system. Domestic banks unable to cope with the increased competitive pressure may fail and countries may experience periods of severe financial instability. Galindo et al. (2013) examine

4 There is ample evidence that foreign banks improve the efficiency of domestic banks (see, e.g., Bonin et al., 2005a,b; Claessens et al., 2001; Focarelli and Pozzolo, 2005; Fries and Taci, 2005; Poghosyan and Poghosyan, 2010). 
whether greater participation of foreign banks exacerbates the adverse effect of a foreign shock on domestic credit growth, and estimate its cost. They find that financial integration captured through foreign bank participation amplifies the impact of international financial shocks on aggregate real credit and real interest rate fluctuations. Cull and Martínez Pería (2013) examine the impact of bank ownership on credit growth in Eastern Europe and Latin America before and during the 2008/ 2009 crisis. They find that loan growth by foreign banks was high prior to the crisis only in Eastern Europe and fell more than that of domestic private banks in these countries during the crisis period, driven largely by an excessive decrease in corporate loans. Similarly, De Haas and van Lelyveld (2014) report that the reduction in the credit growth rate of multinational bank subsidiaries was almost three times faster than domestic banks during the 2008/2009 global crisis, controlling for other bank characteristics.

While foreign bank presence and its implications for local banking systems or financial stability have been investigated in the literature, studies examining the direct effect of foreign banks on macroeconomic stability ${ }^{5}$ are limited. Using these related but separate strands of literature, one can indirectly associate foreign banks with economic stability. Although a consensus has not been reached, foreign banks do have some impact on financial development. ${ }^{6}$ In addition, there is a literature on the contribution of financial development to macroeconomic stability. Among very few theoretical studies, it is shown that the effect of financial development on volatility depends on the stage of the country's development (Aghion et al., 2004) or the type of shocks affecting the economy (Bacchetta and Caminal, 2000).

To our knowledge, only two papers in the literature focus on the association between the presence of foreign banks and economic volatility. Measuring macroeconomic volatility with deviations from the expected employment growth rate, Morgan et al. (2004) show that the share of a state's bank assets that is owned by a multi-state bank holding company is negatively associated with macroeconomic volatility for the period 1976-1994 in the US. Hence, they provide evidence that out-of-state banks had a stabilizing effect on economic activity among US states. When Morgan and Strahan (2004) examine the relationship between foreign banks and macroeconomic volatility for a sample of countries rather than states for the period 1990-1997, they find zero or a positive association between foreign banks and macroeconomic volatility, measured with deviations of real GDP growth and real investment spending growth from their expected growth rates. Their sample period is relatively short and coincides with the early years of the entry of foreign banks into the host countries. The average share of bank assets controlled by

\footnotetext{
5 Klomp and De Haan (2009) provide an excellent review of the literature on macroeconomic volatility.

${ }^{6}$ Detragiache et al. (2008) and Claessens and van Horen (2014) present a negative effect of foreign bank presence on financial development, unlike Bonin et al. (2005a,b), Claessens et al. (2001), Focarelli and Pozzolo (2005), and Fries and Taci (2005).
} 
foreign banks in the majority of their sample countries (except those in Latin America) was small. The average market share of foreign banks was only 18.7 percent for the Latin American countries, in which they observe a positive link with foreign banks and volatility in investment growth but no significant association between foreign banks and output volatility. Moreover, their sample period does not cover a large-scale financial crisis, which may compel foreign banks to change their behaviour.

In this paper, we examine foreign bank presence in Emerging European countries that have substantially altered the financial landscape and governance of banks in these countries. Such banks became dominant in many Central, Eastern and Baltic states; assets of foreign banks in some of the region's countries account for 89 percent to 96 percent of the overall bank assets as of 2013. Considering that a sizeable portion of the private sector credit in Emerging Europe was funded by foreign banks even during the 2008/2009 crisis, we aim to understand how the association between economic stability and foreign participation in banking changes in countries with high foreign bank presence, and over normal and crisis periods.

\section{Empirical methodology}

In this paper, we are particularly interested in the extent to which macroeconomic fluctuations are related to the presence of foreign banks in the domestic market and examine not only output volatility but also its components, mainly the volatility of consumption and investments. ${ }^{7}$ Empirically analyzing the link between macroeconomic volatility and foreign banks includes several challenges. The first challenge is measuring macroeconomic volatility. The second challenge is the potential endogeneity between economic volatility and foreign bank presence. To deal with these challenges, we proceed with the estimations in two steps (see, e.g., Aghion et al., 2009; Morgan et al., 2004). In the first step, we estimate the growth model for three macroeconomic variables (real GDP, real consumption and real investment) to derive predictable movements in their growth rates, controlling for country and year effects. In the second step, we examine the relationship between foreign banks and macroeconomic volatility, measured by the residuals obtained in the first step. We use both ordinary least squares (OLS) and instrumental variable (IV) estimations in the second step.

\footnotetext{
7 Although net export is another component of economic growth volatility, we do not analyze it in this paper. As emphasized in the literature on international aspects of the business cycle (see e.g., Prasad, 1998), net export volatility requires a different empirical framework, including dynamics in the trade balance in response to various macroeconomic shocks. Furthermore, its share in GDP is small compared to consumption and investment.
} 


\subsection{The model}

The specification of the regressions for GDP, consumption and investment growth rates are broadly similar to Bekaert et al. (2005). Thus, the following fixed effects model is estimated in the first step $^{8}$ :

$$
\mathrm{GROWTH}_{i t}=\eta_{i}+\mu_{t}+\Theta \mathrm{CONTROL} L_{i t}+\varepsilon_{i t}
$$

where $\eta_{i}, \mu_{t}$ and $C O N T R O L_{i t}$ represent country and year fixed effects and a vector of control variables, respectively. Control variables include trade openness of a country, measured as the GDP share of total exports and imports, foreign direct investment to GDP ratio, external (private and public) debt as a percentage of GDP, rate of population growth, years of secondary education as a proxy for human capital, government consumption-to-GDP ratio, unemployment rate, life expectancy and inflation rate of country $i$ at time $t$. In the model, we also include the lagged values of the growth rates in real GDP or real consumption or real investment expenditures. ${ }^{9}$

The residuals estimated in the first-step regressions ${ }^{10}$ are used as proxies for growth rate volatilities, as in Morgan et al. (2004). In general, studies that examine macroeconomic volatility use standard deviations of the growth rate as a measure of volatility. However, constructing time series volatilities by rolling windows with fixed sizes and computing standard deviations for every window generates a serial correlation in the resulting time series. Moreover, in the rolling-window approach, outliers have a level effect and it is not easy to identify shocks. Because we try to estimate how the relationship between foreign banks and macroeconomic volatility changed during the global crisis, we do not employ this approach. Our volatility measure, $V O L_{i t}$, is defined as the absolute value of the deviation of the actual growth rates from the estimated growth rates of output, consumption and investment for country $i$ and year $t$ using the model specified in Equation (1).

To examine the relationship between foreign banks and macroeconomic volatility, we estimate the following model (Model I):

$$
\begin{aligned}
\text { VOL }_{i t}= & \alpha+\beta \text { Foreign Banks }_{i t}+\gamma \text { Bank Concentration }_{i t} \\
& +\psi \text { Private Credits }_{i t}+\delta R E E R_{i t}+u_{i t} .
\end{aligned}
$$

Foreign Banks is our main variable of interest and is measured by the share of foreign bank assets in the total banking system. As mentioned above, the presence of

${ }^{8}$ We estimate different models for each component of GDP by variables such as expected output or rule of law, as in Beck and Laeven (2006). However, we find no variable that may affect consumption and investment growth differently and hence we use the same model to predict the growth rate of real GDP and its components.

9 Modelling growth is difficult in time series analysis. Several variables affect growth, and some econometric problems, such as endogeneity, arise. We follow the solution suggested by Sims (1980) and use the lagged values of a dependent variable as an explanatory variable.

10 The results of the models estimated in the first step are presented in the Appendix (Table A2). 
foreign banks usually contributes to the institutional strength of the banking system by increasing resilience to failures, especially local failures; but heavy reliance on foreign banks could be destabilizing if they transmit foreign shocks across borders. Therefore, we do not have a priori expectations regarding the sign of the coefficient of Foreign Banks in explaining macroeconomic volatility.

The estimation of Model I by OLS may suffer from an endogeneity bias because the presence of foreign banks and other financial variables are likely to be driven by business cycle fluctuations to some extent. In the literature, there is evidence that foreign bank participation increases in periods of high volatility. For example, Cardim de Carvalho (2000) shows that the banking crisis of 1995 created an opportunity for foreign banks to acquire local banks in Brazil. Havrylchyk and Jurzyk (2011) show that foreign banks entered some Central and Eastern European countries when the economies were poor and growing slowly in the period 1993-2005. In a cross-country study, Mathieson and Roldos (2001) show that a banking crisis raises foreign participation in the banking system by about 10 percentage points. On the other hand, foreign banks may reduce their assets in host countries when they observe volatility as experienced during the 2008/2009 global crisis (Claessens and van Horen, 2014). We test the endogeneity between foreign bank and volatility variables using the Durban and the Wu-Hausman tests. ${ }^{11}$ We fail to reject the null hypothesis that they are exogenous. Nevertheless, we also use instrumental variable (IV) approach in the estimations. We follow Morgan and Strahan (2004) in the determination of IVs and use language dummy variables, ${ }^{12}$ the average foreign bank assets-to-GDP ratio and the contribution of the country's bank assets to the total bank assets in each language group in each year as IVs in the estimations. ${ }^{13}$

In the model, we control for other factors that might affect macroeconomic volatility: concentration in the banking sector (Bank Concentration), financial development (Private Credits) and change in the real effective exchange rate (REER). From the period 1998-2002, Emerging European countries significantly restructured their banking industries. Mergers and acquisitions, failures, entries of new financial institutions and subsequent bank consolidations affected the competitive environment in the banking sectors of regional economies. Banking sector concentration, which is defined as the asset shares of the largest five banks, is included in the model in order to control for the effect of possible problems in a few large institutions or the existence of higher financial intermediation costs in concentrated markets on aggregate lending and macroeconomic stability.

11 The results of these tests are reported at the bottom of Tables 2-4 for GDP, consumption and investment volatility models.

12 Based on their origins, we classify the countries into the following language groups: Albanian, Uralic, Baltic, Latin, Turkish, Southern Slavic, Eastern Slavic and Western Slavic.

${ }^{13}$ When we test the joint significance of all of the instruments, we see that the instruments are jointly significantly different from zero, with a $P$-value of $0.000(F(9,267)=26.9497)$. The adjusted $R^{2}$ is 0.5813 and the partial $R^{2}$ is 0.4760 . These test results suggest that our instruments are strong. 
We include Private Credits in our model to control for financial development in each country. Although the theoretical literature outlines various mechanisms through which financial development can affect macroeconomic volatility, empirically there is no consensus on the effects of financial development, which is proxied with a private credits-to-GDP ratio. Deeper financial systems can dampen volatility by alleviating firms' cash constraints, particularly in economies with tight international financial constraints (Beck et al., 2006; Caballero and Krishnamurthy, 2001; Dabla-Norris and Srivisal, 2013). At the same time, financial development can lead to more risk-taking or facilitate overleverage, both of which could potentially drive up volatility (Shleifer and Vishny, 2010).

The increasing absorptive capacity of capital through the entry of foreign banks in Emerging European countries is accompanied by growing current account deficits. A real exchange rate appreciation from large capital inflows may cause a loss of competitiveness in these countries. Moreover, in many Central and Eastern European countries, large portions of domestic credit are denominated in foreign currency (Mihaljek, 2011). Hence, borrowers' creditworthiness and their ability to service debt rely heavily on exchange rate stability. In our model, we include the natural logarithm of the real exchange rate as another variable to explain fluctuation in economic growth.

To determine whether the relationship between foreign bank presence and macroeconomic volatility changed during the crisis years of our sample, we create interaction variables between Foreign Bank and year dummy variables during the pre-crisis $\left(Y_{2007}\right)$, crisis $\left(Y_{2008}, Y_{2009}\right)$ and post-crisis periods $\left(Y_{2010}, Y_{2011}, Y_{2012}\right.$ and $Y_{2013}$ ). We then estimate another model (Model II) by including these interaction variables to Model I. Considering the interconnectedness of financial institutions in this region to Western Europe and troubled intermediaries even in 2007, ${ }^{14}$ we analyze how this relationship changed starting from 2007.

\subsection{Data}

We examine the relationship between foreign bank presence and macroeconomic volatility for a sample of 20 Emerging European countries. Although most banking systems in the sample countries were bought and shaped by Western European banking groups, there are some differences in the banking systems of countries we examine in this study. The average share of foreign bank assets in the total assets of the banking systems is more than 60 percent in the majority of the countries; however, it is $<25$ percent in Belarus, Slovenia, the Russian Federation and Turkey. Table 1 presents the mean values of the variables used in the analysis at the country level for the period between 1998 and 2013. Detailed definitions, other descriptive statistics and data sources of the variables are reported in the Appendix in Table A3.

14 The bailout of IKB Deutsche Industriebank in July 2007 and the suspension of the money market funds of French BNP Paribas and of the mortgage investments of Dutch lender NIBC Holding in August 2007 are some examples of then-troubled European institutions. 


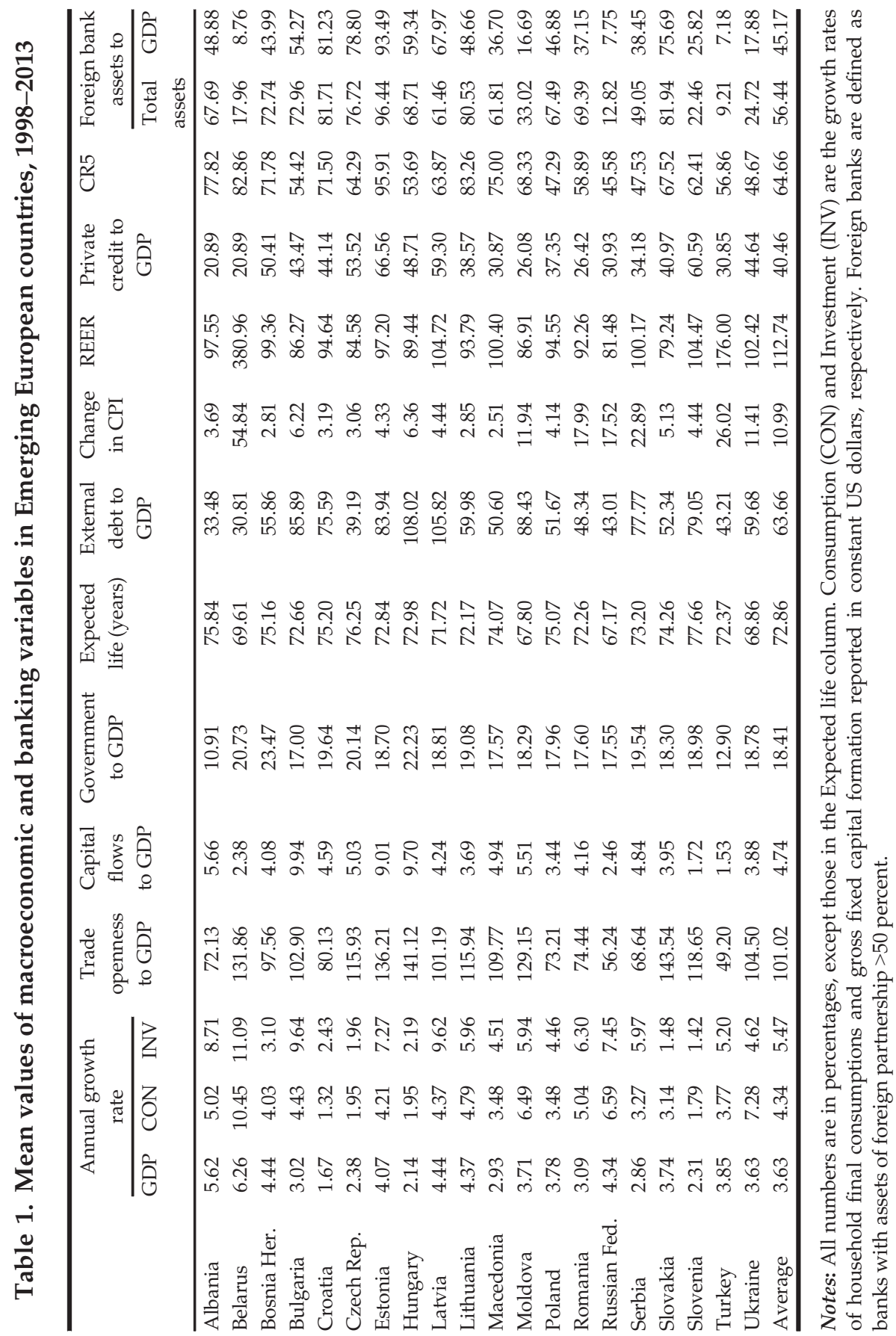


Over the sample period, the mean growth rate of real investment (5.47 percent) was notably higher in the region compared to mean growth rates of real GDP (3.63 percent) and real private consumption (4.34 percent). There is some variation among countries in terms of growth rates of GDP and its components. For example, average real investment annual growth rate in Belarus, Bulgaria and Latvia was around or above 10 percent, whereas it was around 2 percent in Croatia (2.43 percent), the Czech Republic (1.96 percent), Hungary (2.16 percent), the Slovak Republic (1.48 percent) and Slovenia (1.42 percent). Similarly, average real consumption annual growth rate in Belarus was slightly above 10 percent but it was below 2 percent in Croatia (1.32 percent), Hungary (1.95 percent) and Slovenia (1.79 percent).

Figures $1 \mathrm{~A}-\mathrm{F}$ show the growth rates of real GDP, real consumption and real investment in our sample countries, grouped as Central European and Baltic (CEB) and South Eastern European (SEE) countries for presentation purposes. Even though the growth rate in GDP had been stable before the crisis in our sample countries, the growth rates in all countries declined in 2009. The decline was more in $\mathrm{CEB}$ countries. The growth rate in real investments also shows more variation in CEB countries than in SEE countries. Moreover, the decline in real investment expenditures in 2009 was three times more than the decline in real output and real consumption expenditures in most of the sample countries.

Since the late 1990s, the presence of foreign-owned banks in Emerging European countries has increased dramatically (Figures 2A-B). The share of foreign banks on the overall banking sector in most of the region's countries seemed to have stabilized by 2005. In addition to increased penetration of foreign banks in domestic banking systems, we observe that the importance of foreign banks in the real economy (i.e., Foreign Bank Assets-to-GDP ratio) increased in all the Emerging European countries over the sample period (Figures 2C-D).

The entry of foreign banks also influenced competition in the banking industry in these countries. We report in Table 1 that on average, 64.66 percent of total banking assets were controlled by the five largest banks (CR5), suggesting a relatively competitive banking market among the sample countries. Yet, there are also some significant variations in banking concentration among these countries. For example, in the 1998-2013 period, the average ratio of the five largest banks in Estonia amounted to almost 96 percent of total assets, while it was below 50 percent in Poland, the Russian Federation, Serbia and Ukraine.

The financial development indicator (namely, domestic credit to the private sector by deposit of money in banks and other financial institutions normalized by GDP) was, on average, 40.5 percent during the sample period. 
Figure 1. GDP, consumption and investment growth rates in Central Eastern European and Baltic (CEB) and South Eastern European (SEE) countries, 1998-2013.

(A) Real GDP growth rate in CEB countries; (B) Real GDP growth rate in SEE countries; (C) Real consumption growth rate in CEB countries; (D) Real consumption growth rate in SEE countries; (E) Real investment growth rate in CEB countries;

(F) Real investment growth rate in SEE countries

(a) Real GDP Growth Rate in CEB Countries

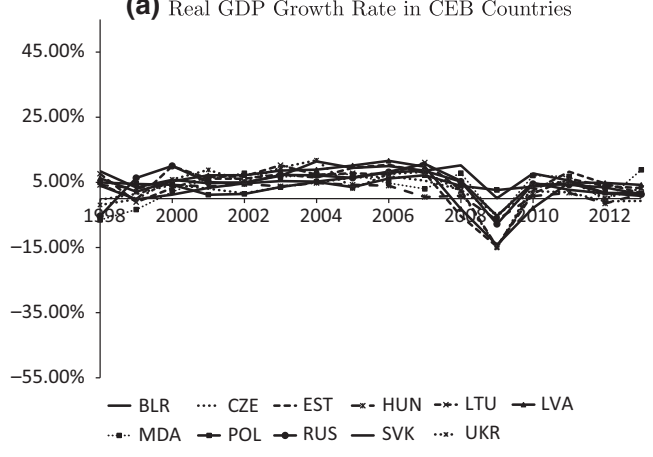

(c) Real Consumption Growth Rate in CEB Countries

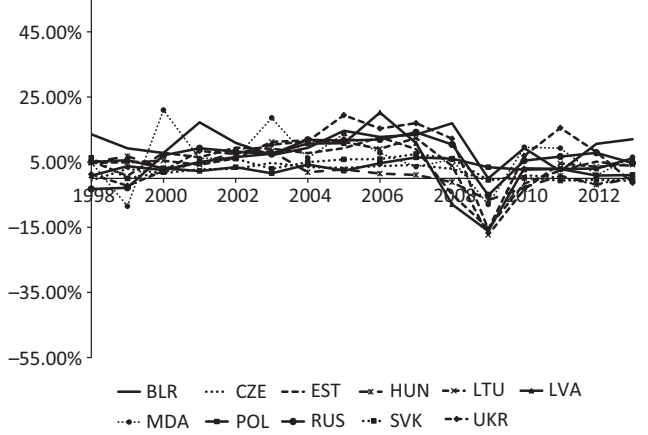

(e) Real Investment Growth Rate in CEB Countries

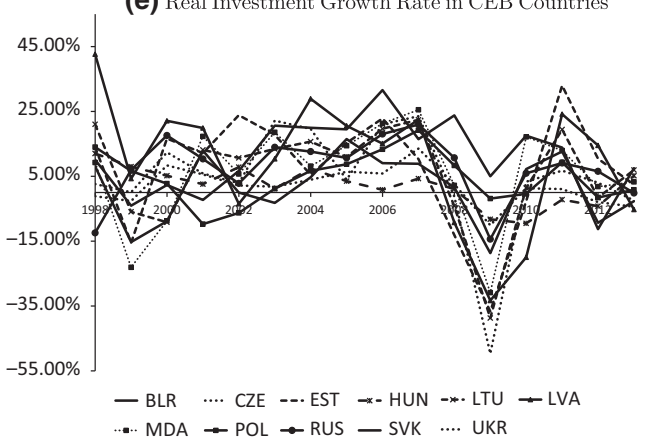

(b) Real GDP Growth Rate in SEE Countries

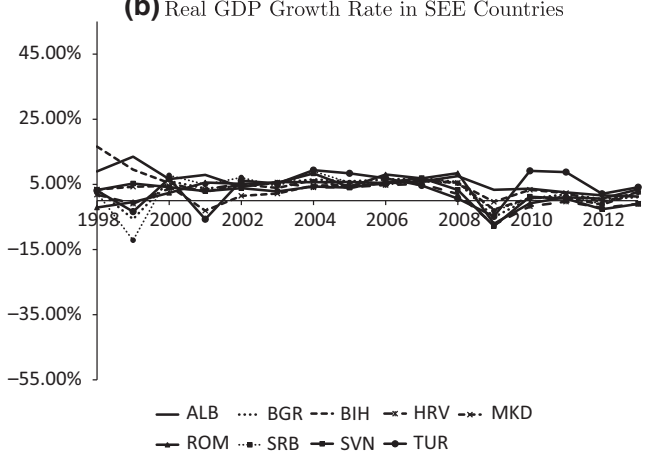

(d) Real Consumption Growth Rate in SEE Countries

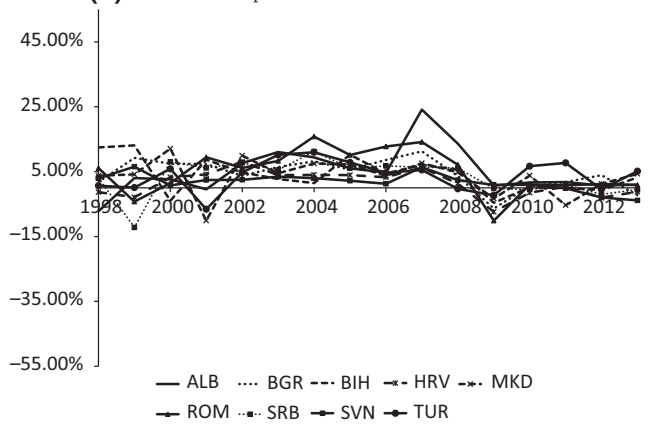

(f) Real Investment Growth Rate in SEE Countries

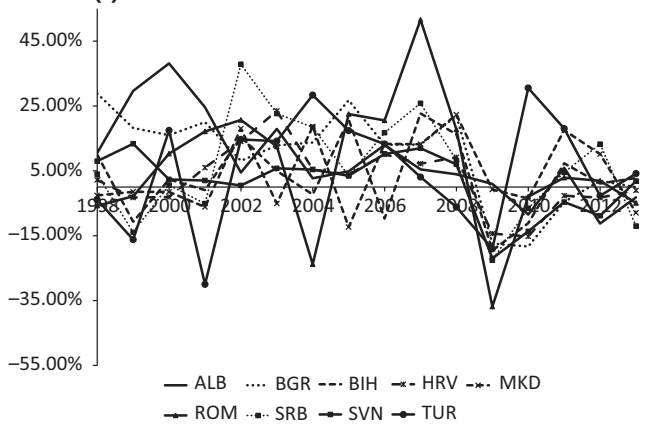


Figure 2. Foreign banks in Emerging European countries, 1998-2013. (A) Foreign bank assets to total assets in CEB; (B) Foreign bank assets to total assets in SEE; (C) Foreign bank assets to GDP in CEB; (D) Foreign bank assets to GDP in SEE

(a) Foreign Bank Assets to Total Assets in CEB

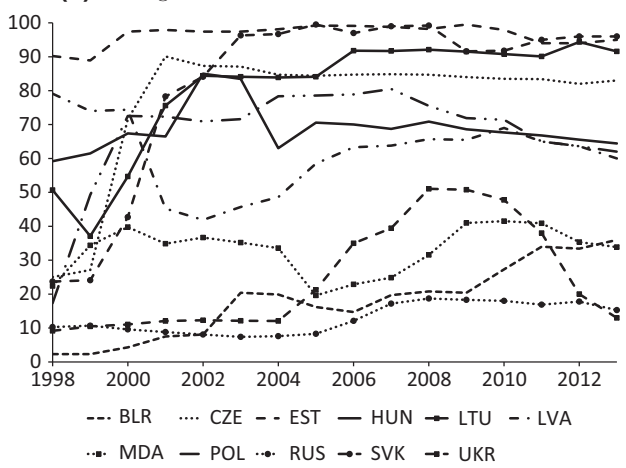

(c) Foreign Bank Assets to GDP in CEB

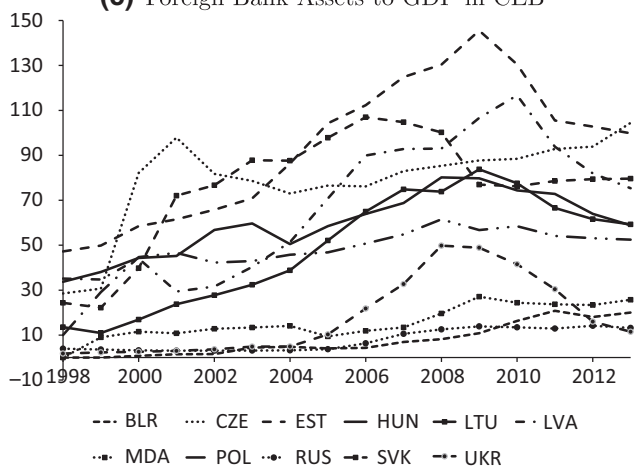

(b) Foreign Bank Assets to Total Assets in SEE

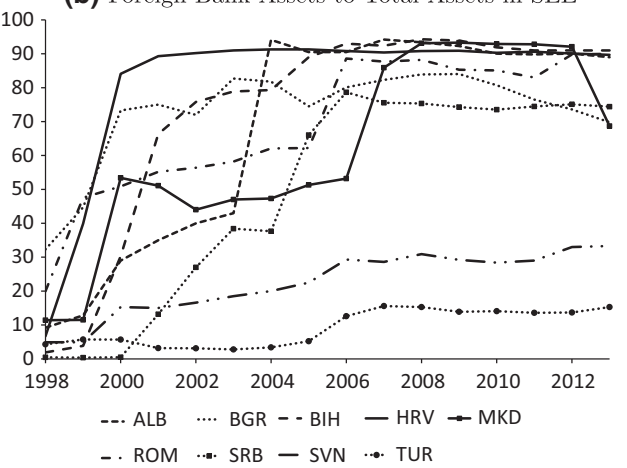

(d) Foreign Bank Assets to GDP in SEE

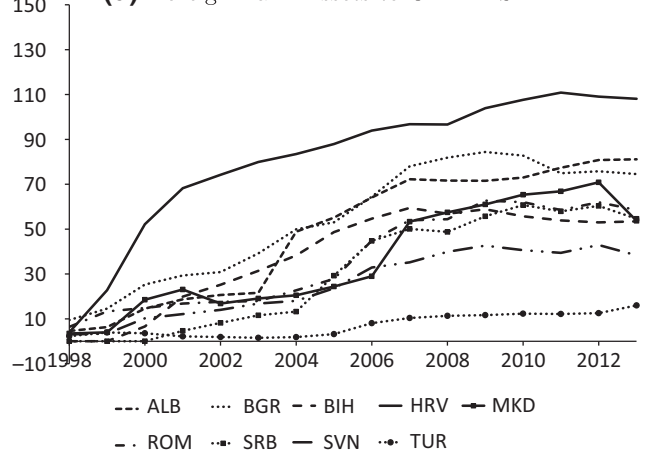

\section{Empirical findings}

We use the absolute values of residuals from the first-step regressions as measures of unexpected changes or volatility of real GDP, consumption and investment. The empirical results of the second-step estimations using OLS and IV estimations that examine the relationship between foreign banks and macroeconomic volatility are presented in Tables 2-4.

Table 2, Panel A presents the estimated coefficients for Models I and II, explaining the volatility of real GDP growth rate. Regardless of the estimation method used, we observe a negative and significant association between the share of foreign banks in the banking system and output volatility, controlling for other factors that might affect volatility. Our results suggest that an increase in the asset 
Table 2. Foreign bank presence and volatility in real GDP growth rate

\begin{tabular}{|c|c|c|c|c|}
\hline \multicolumn{5}{|c|}{ Panel A: Dependent variable: Real GDP growth volatility } \\
\hline & Model I & Model II & Model I & Model II \\
\hline \multirow[t]{2}{*}{ Intercept } & 2.538 & $4.260^{*}$ & 2.841 & $4.535^{*}$ \\
\hline & $(2.537)$ & $(2.567)$ & $(2.557)$ & $(2.582)$ \\
\hline \multirow[t]{2}{*}{ Bank Concentration } & $0.013^{*}$ & $0.014^{*}$ & $0.017^{* *}$ & $0.017^{* *}$ \\
\hline & $(0.008)$ & $(0.007)$ & $(0.008)$ & $(0.007)$ \\
\hline \multirow[t]{2}{*}{ REER } & -0.314 & -0.619 & -0.390 & -0.680 \\
\hline & $(0.552)$ & $(0.564)$ & $(0.555)$ & $(0.566)$ \\
\hline \multirow[t]{2}{*}{ Private Credits } & 0.007 & -0.003 & $0.010^{*}$ & -0.001 \\
\hline & $(0.006)$ & $(0.006)$ & $(0.007)$ & $(0.007)$ \\
\hline \multirow[t]{2}{*}{ Foreign Banks } & $-0.008^{* *}$ & $-0.013^{* * *}$ & $-0.013^{* *}$ & $-0.018^{* * *}$ \\
\hline & $(0.003)$ & $(0.003)$ & $(0.006)$ & $(0.006)$ \\
\hline \multirow[t]{2}{*}{$Y_{2007} \times$ Foreign Banks } & & 0.003 & & 0.006 \\
\hline & & $(0.004)$ & & $(0.006)$ \\
\hline \multirow[t]{2}{*}{$Y_{2008} \times$ Foreign Banks } & & $0.014^{*}$ & & $0.016^{*}$ \\
\hline & & $(0.007)$ & & $(0.009)$ \\
\hline \multirow{2}{*}{$Y_{2009} \times$ Foreign Banks } & & $0.035^{* * *}$ & & $0.034^{* * *}$ \\
\hline & & $(0.010)$ & & $(0.010)$ \\
\hline \multirow[t]{2}{*}{$Y_{2010} \times$ Foreign Banks } & & 0.007 & & 0.007 \\
\hline & & $(0.005)$ & & $(0.005)$ \\
\hline \multirow[t]{2}{*}{$Y_{2011} \times$ Foreign Banks } & & $0.010^{* *}$ & & $0.009^{*}$ \\
\hline & & $(0.005)$ & & $(0.005)$ \\
\hline \multirow[t]{2}{*}{$Y_{2012} \times$ Foreign Banks } & & -0.000 & & -0.000 \\
\hline & & $(0.003)$ & & $(0.004)$ \\
\hline \multirow[t]{2}{*}{$Y_{2013} \times$ Foreign Banks } & & 0.007 & & 0.007 \\
\hline & & $(0.005)$ & & $(0.007)$ \\
\hline \multicolumn{5}{|l|}{ Test of endogeneity } \\
\hline \multicolumn{3}{|l|}{ Durban $(P$-value $)$} & 0.1971 & 0.1941 \\
\hline \multicolumn{3}{|l|}{ Wu-Hausman ( $P$-value $)$} & 0.2017 & 0.2209 \\
\hline \multicolumn{5}{|c|}{ Test of overidentifying restrictions } \\
\hline \multicolumn{3}{|l|}{ Hansen $J$-test ( $P$-value) } & 0.0165 & 0.1262 \\
\hline Adjusted $R^{2}$ & 0.010 & 0.113 & 0.013 & 0.097 \\
\hline F-statistics & 1.69 & $4.25^{* * *}$ & 1.92 & $3.72^{* * *}$ \\
\hline$N$ & 281 & 281 & 280 & 280 \\
\hline
\end{tabular}


Table 2. (Continued)

\begin{tabular}{lccccccr}
\hline \multicolumn{7}{l}{ Panel B: Coefficient on Foreign Banks in years } \\
& $\mathbf{2 0 0 7}$ & $\mathbf{2 0 0 8}$ & $\mathbf{2 0 0 9}$ & $\mathbf{2 0 1 0}$ & $\mathbf{2 0 1 1}$ & $\mathbf{2 0 1 2}$ & $\mathbf{2 0 1 3}$ \\
\hline $\begin{array}{l}\text { OLS Estimations } \\
\begin{array}{l}\text { Foreign Banks } \\
\text { IV Estimations }\end{array}\end{array}$ & $-0.010^{*}$ & 0.001 & $0.022^{* * *}$ & -0.006 & -0.003 & $-0.013^{* *}$ & -0.007 \\
\begin{tabular}{l} 
Foreign Banks \\
\hline
\end{tabular} & -0.012 & -0.002 & $0.017^{* *}$ & -0.011 & -0.008 & $-0.019^{* *}$ & -0.011 \\
\hline
\end{tabular}

Notes: The numbers in parentheses in Panel A are heteroscedasticity consistent standard errors. In Panel B, F-statistics test the hypothesis that the coefficient of Foreign Banks in that year equals zero. *, ** and *** denote statistical significance at the 10 percent, 5 percent and 1 percent levels, respectively.

size of foreign banks in the banking system of the host country had a significant dampening effect on the volatility of real GDP growth rates over the sample period. Although these findings seem to contradict the results of Morgan and Strahan (2004), we examine this relationship for a drastically different sample. The majority of Emerging European countries in our sample have been experiencing extreme dominance of foreign banks. Nevertheless, our results support the theoretical findings of Aghion et al. (1999) and Caballero and Krishnamurthy (2001) that foreign lenders smooth fluctuations by supplying scarce capital in emerging markets. Moreover, as highlighted by Grittersova (2012), increasing foreign bank presence in the total banking industry can be considered a provision of reputational capital to host countries and makes their commitments more credible, suggesting output stability in the host country.

When we focus on the period 2007-2013, we observe that the coefficients of Foreign Banks increased significantly in the crisis years, 2008 and 2009, and in 2011 (Table 2, Panel A). The negative relationship between foreign banks and volatility continued in 2007, but this relationship turned positive in 2009, as reported in Table 2, Panel B. Berglöf et al. (2010) argue that foreign banks have a mitigating effect on output decline in Central and Eastern European countries by softening bank lending outflows at the peak of crises, and thus preventing currency collapses and systemic banking crises in this region in periods of global crisis. Our findings, however, suggest that the large presence of these banks amplified output growth volatility in 2009 among sample countries, supporting the evidence provided by De Haas and van Lelyveld (2014), Cull and Martínez Pería (2013) and Claessens and van Horen (2014). These authors report that foreign banks reduced their lending earlier and faster than domestic banks during the recent crisis in Eastern Europe. However, the amplifying effect of these banks on output volatility during the crisis period seems to disappear after 2009 as we observe a significant tranquilizing effect of foreign banks on output volatility, especially in 2012 (Table 2, Panel B). 
Table 3. Foreign bank presence and volatility in real consumption growth rate

Panel A: Dependent variable: Real consumption growth volatility

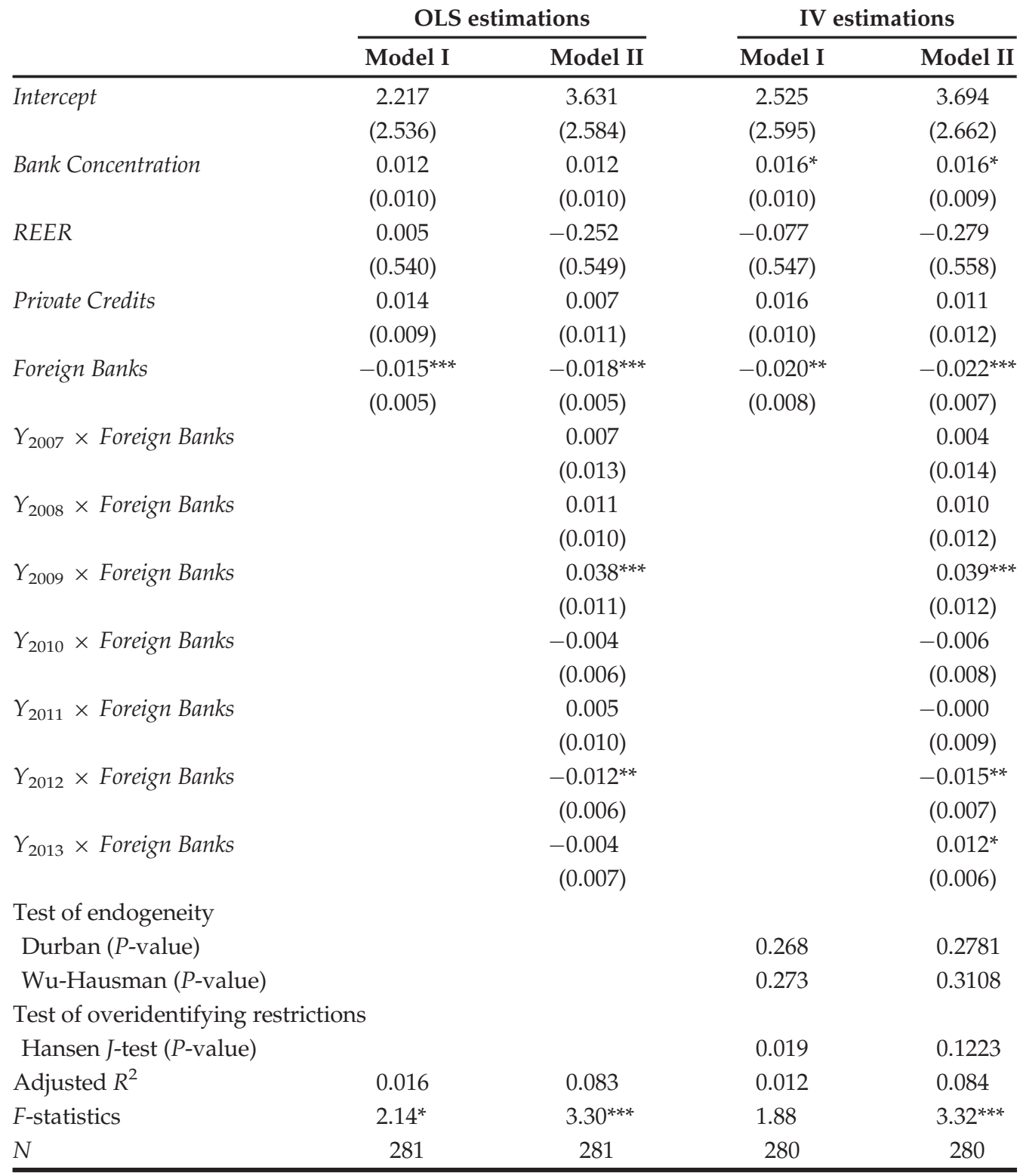


Table 3. (Continued)

\begin{tabular}{|c|c|c|c|c|c|c|c|}
\hline \multicolumn{8}{|c|}{ Panel B: Coefficient on Foreign Banks in years } \\
\hline & 2007 & 2008 & 2009 & 2010 & 2011 & 2012 & 2013 \\
\hline \multicolumn{8}{|c|}{ OLS estimations } \\
\hline Foreign Banks & -0.012 & -0.007 & $0.020^{* *}$ & $-0.023^{* *}$ & -0.013 & $-0.030^{* * *}$ & $-0.022^{* *}$ \\
\hline F-statistics & 1.66 & 0.67 & 4.66 & 5.78 & 1.77 & 8.81 & 4.01 \\
\hline \multicolumn{8}{|l|}{ IV estimations } \\
\hline Foreign Banks & -0.018 & -0.012 & 0.017 & $-0.029^{* *}$ & $-0.022^{*}$ & $-0.038^{* * *}$ & $-0.034^{* * *}$ \\
\hline F-statistics & 2.58 & 1.18 & 2.15 & 6.32 & 3.67 & 9.54 & 6.74 \\
\hline
\end{tabular}

Notes: The numbers in parentheses in Panel A are heteroscedasticity consistent standard errors. In Panel B, Fstatistics test the hypothesis that the coefficient of Foreign Banks in that year equals zero. *,** and *** denote statistical significance at the 10 percent, 5 percent and 1 percent levels, respectively.

Among the control variables, bank concentration is mainly found to be positively and significantly associated with output growth volatility, supporting evidence in the literature, that is, that bank concentration may lead to higher intermediation margins which in turn could increase macroeconomic instability. We observe no significant impact of real exchange rate and a weakly significant impact of financial development on output volatility.

When volatility in consumption growth is examined, the coefficient of Foreign Banks is found to be negative and significant for both models, suggesting a dampening effect of foreign banks on the fluctuations of private consumption expenditures (Table 3). The coefficients increased significantly in 2009 but declined significantly in 2012. These banks are found to have a significant amplifying effect on consumption volatility in 2009, but no significant coefficient is observed in 2008. Although Cull and Martínez Pería (2013) showed that consumer loans declined significantly both before and during the crisis in Eastern European countries, we do not observe a significant effect of credit crunch in the region on consumption volatility in 2008 . Moreover, our findings suggest that the contraction in credit supply to households that is found in other studies and foreign banks' amplifying effect on consumption growth volatility that we find seem to have only a temporary impact because almost all of the coefficients of Foreign Banks after 2009 are negative and mostly significant, indicating that foreign banks have continued to facilitate consumption smoothing and lower consumption volatility since the crisis in Emerging Europe (Table 3, Panel B).

The panel regression results for volatility of real investments are reported in Table 4. No significant impact of foreign bank shares is found in explaining investment growth volatility during normal periods. However, we observe that foreign banks are positively and significantly associated with volatility of investment growth rates in 2009 (Table 4, Panel B). This finding is not surprising because Cull and Martínez Pería (2013) show that in Eastern Europe the decline in total lending 
Table 4. Foreign bank presence and volatility in real investment growth rate

Panel A: Dependent variable: Real investment growth volatility

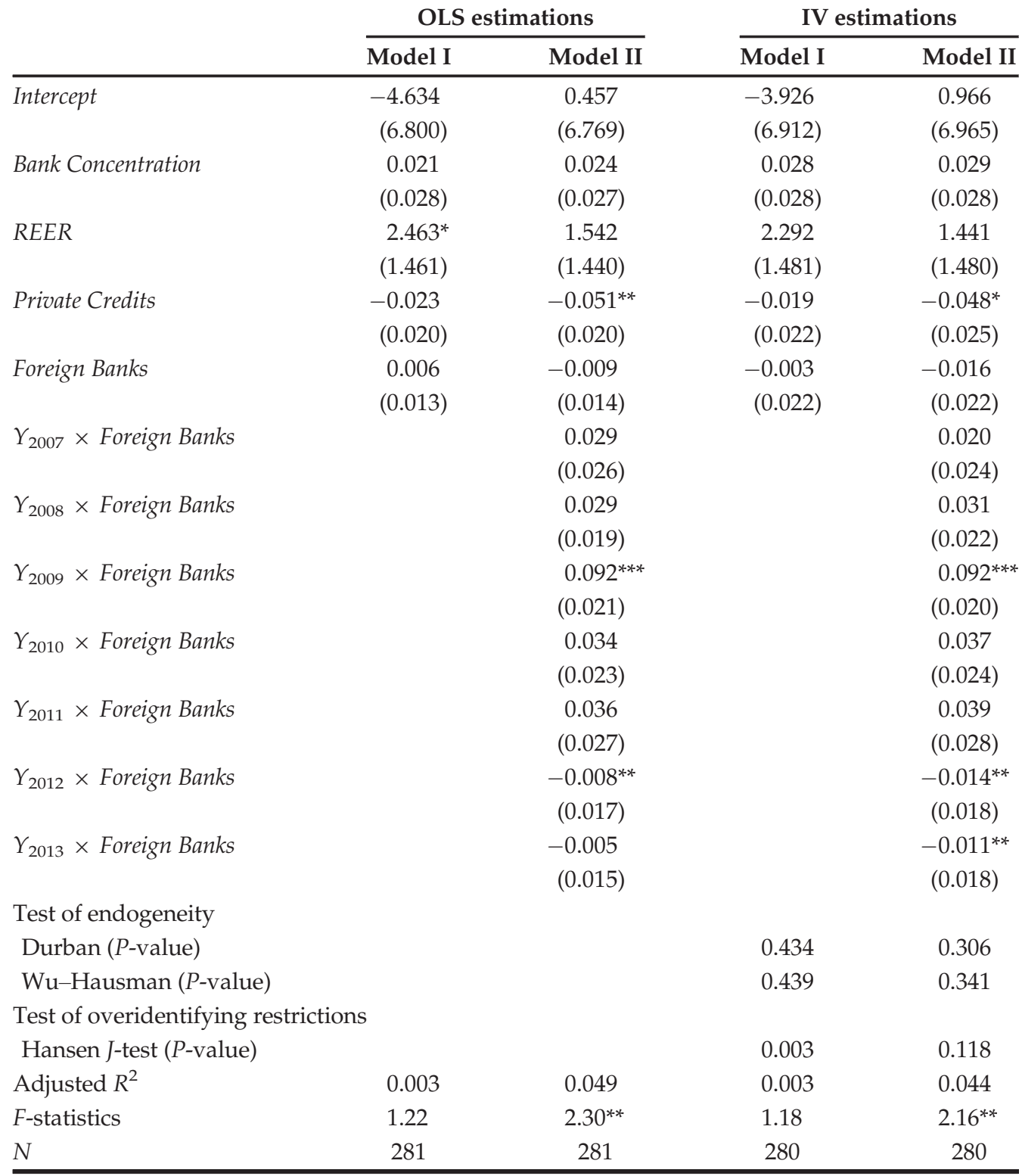


Table 4. (Continued)

\begin{tabular}{|c|c|c|c|c|c|c|c|}
\hline \multicolumn{8}{|c|}{ Panel B: Coefficient on Foreign Banks in years } \\
\hline & 2007 & 2008 & 2009 & 2010 & 2011 & 2012 & 2013 \\
\hline \multicolumn{8}{|c|}{ OLS estimations } \\
\hline Foreign Banks & 0.020 & 0.020 & $0.083^{* * *}$ & 0.025 & 0.027 & -0.017 & -0.014 \\
\hline F-statistics & 0.77 & 0.74 & 11.96 & 1.05 & 1.16 & 0.42 & 0.26 \\
\hline \multicolumn{8}{|l|}{ IV estimations } \\
\hline Foreign Banks & 0.004 & 0.015 & $0.076^{* *}$ & 0.022 & 0.023 & -0.030 & -0.027 \\
\hline F-statistics & 0.02 & 0.26 & 6.65 & 0.54 & 0.59 & 0.89 & 0.65 \\
\hline
\end{tabular}

Notes: The numbers in parentheses in Panel A are heteroscedasticity consistent standard errors. In Panel B, Fstatistics test the hypothesis that the coefficient of Foreign Banks in that year equals zero. $*, * *$ and $* * *$ denote statistical significance at the 10 percent, 5 percent and 1 percent levels, respectively.

by foreign banks during the crisis was primarily driven by reductions in corporate loans.

We find a negative and significant association between financial development, that is, Private Credits and investment growth volatility during the period 19982013. This finding is consistent with previous findings (see e.g., Dabla-Norris and Srivisal, 2013) as deeper financial systems facilitate greater diversification, reduce dependence of firms' investment decisions on internal cash flows and dampen fluctuations. ${ }^{15}$

\section{Robustness}

We employ four robustness checks in our analysis. First, we measure the presence of foreign banks in the local market using the ratio of foreign bank assets to GDP as another proxy, indicating the importance of foreign banks in the real economy, as in Buch et al. (2010). Table 5 reports only the estimated coefficients of foreign-bank related variables in the second step and the results of the hypothesis testing whether the coefficient of Foreign Banks in each year of the 2007-2013 period is significantly different from zero. The findings for GDP, consumption and investment growth volatilities are similar to those reported in Tables $2-4$. In particular, in the output and consumption regressions, the coefficients of Foreign Banks in explaining

\footnotetext{
${ }^{15}$ It can be argued that foreign banks may use different investment strategies during periods of unexpected growth shortfalls (negative deviations) compared to periods when key macroeconomic variables are growing more than expected (positive deviations). We separately examine how foreign banks and macroeconomic fluctuations are related during these periods. We find significant and positive associations between foreign bank presence and output volatility but no significant association between foreign banks and investment volatility in the excess growth and shortfall growth years. However, foreign banks are found to play a significant consumption smoothing role, especially in shortfall periods.
} 
Table 5. Foreign bank assets to GDP ratio (alternative measure)

\begin{tabular}{|c|c|c|c|c|c|c|}
\hline & \multicolumn{2}{|c|}{$\begin{array}{l}\text { Real GDP growth } \\
\text { volatility }\end{array}$} & \multicolumn{2}{|c|}{$\begin{array}{l}\text { Real consumption } \\
\text { growth volatility }\end{array}$} & \multicolumn{2}{|c|}{$\begin{array}{l}\text { Real investment } \\
\text { growth volatility }\end{array}$} \\
\hline & OLS & IV & OLS & IV & OLS & IV \\
\hline \multicolumn{7}{|l|}{ Model I } \\
\hline Foreign Banks & $\begin{array}{c}-0.008^{* *} \\
(0.004)\end{array}$ & $\begin{array}{c}-0.017^{* *} \\
(0.007)\end{array}$ & $\begin{array}{l}-0.016^{* * *} \\
(0.006)\end{array}$ & $\begin{array}{l}-0.031^{* * *} \\
(0.010)\end{array}$ & $\begin{array}{c}0.006 \\
(0.014)\end{array}$ & $\begin{array}{r}-0.021 \\
(0.025)\end{array}$ \\
\hline \multicolumn{7}{|l|}{ Model II } \\
\hline Foreign Banks & $\begin{array}{l}-0.016^{* * *} \\
(0.004)\end{array}$ & $\begin{array}{l}-0.022^{* * *} \\
(0.007)\end{array}$ & $\begin{array}{l}-0.022^{* * *} \\
(0.006)\end{array}$ & $\begin{array}{l}-0.033^{* * *} \\
(0.009)\end{array}$ & $\begin{array}{r}-0.019 \\
(0.014)\end{array}$ & $\begin{array}{r}-0.035 \\
(0.024)\end{array}$ \\
\hline$Y_{2007} \times$ Foreign Banks & $\begin{array}{c}0.008 \\
(0.006)\end{array}$ & $\begin{array}{c}0.009 \\
(0.007)\end{array}$ & $\begin{array}{c}0.008 \\
(0.013)\end{array}$ & $\begin{array}{c}0.004 \\
(0.014)\end{array}$ & $\begin{array}{c}0.037^{*} \\
(0.022)\end{array}$ & $\begin{array}{c}0.026 \\
(0.023)\end{array}$ \\
\hline$Y_{2008} \times$ Foreign Banks & $\begin{array}{l}0.020^{*} \\
(0.010)\end{array}$ & $\begin{array}{l}0.020^{* *} \\
(0.010)\end{array}$ & $\begin{array}{c}0.019 \\
(0.013)\end{array}$ & $\begin{array}{c}0.016 \\
(0.014)\end{array}$ & $\begin{array}{l}0.045^{* *} \\
(0.022)\end{array}$ & $\begin{array}{l}0.043^{*} \\
(0.024)\end{array}$ \\
\hline$Y_{2009} \times$ Foreign Banks & $\begin{array}{l}0.038^{* * *} \\
(0.010)\end{array}$ & $\begin{array}{l}0.039^{* * *} \\
(0.010)\end{array}$ & $\begin{array}{l}0.043^{* * *} \\
(0.012)\end{array}$ & $\begin{array}{l}0.044^{* * *} \\
(0.012)\end{array}$ & $\begin{array}{l}0.102^{* * *} \\
(0.021)\end{array}$ & $\begin{array}{l}0.101^{* * *} \\
(0.021)\end{array}$ \\
\hline$Y_{2010} \times$ Foreign Banks & $\begin{array}{l}0.011^{* *} \\
(0.005)\end{array}$ & $\begin{array}{c}0.009^{*} \\
(0.005)\end{array}$ & $\begin{array}{c}0.000 \\
(0.008)\end{array}$ & $\begin{array}{r}-0.005 \\
(0.009)\end{array}$ & $\begin{array}{l}0.052^{* *} \\
(0.024)\end{array}$ & $\begin{array}{c}0.048^{*} \\
(0.025)\end{array}$ \\
\hline$Y_{2011} \times$ Foreign Banks & $\begin{array}{l}0.015^{* *} \\
(0.006)\end{array}$ & $\begin{array}{l}0.012^{* *} \\
(0.006)\end{array}$ & $\begin{array}{c}0.005 \\
(0.010)\end{array}$ & $\begin{array}{c}0.001 \\
(0.010)\end{array}$ & $\begin{array}{l}0.070^{* *} \\
(0.031)\end{array}$ & $\begin{array}{r}0.055^{*} \\
(0.031)\end{array}$ \\
\hline$Y_{2012} \times$ Foreign Banks & $\begin{array}{c}0.004 \\
(0.004)\end{array}$ & $\begin{array}{c}0.001 \\
(0.005)\end{array}$ & $\begin{array}{r}-0.009 \\
(0.008)\end{array}$ & $\begin{array}{r}-0.014^{*} \\
(0.009)\end{array}$ & $\begin{array}{c}0.003 \\
(0.017)\end{array}$ & $\begin{array}{r}-0.008 \\
(0.018)\end{array}$ \\
\hline$Y_{2013} \times$ Foreign Banks & $\begin{array}{l}0.010^{* *} \\
(0.005)\end{array}$ & $\begin{array}{c}0.008 \\
(0.006)\end{array}$ & $\begin{array}{r}-0.000 \\
(0.008)\end{array}$ & $\begin{array}{r}-0.009 \\
(0.008)\end{array}$ & $\begin{array}{c}0.009 \\
(0.016)\end{array}$ & $\begin{array}{r}-0.006 \\
(0.020)\end{array}$ \\
\hline \multicolumn{7}{|c|}{ Coefficient on Foreign Banks in years } \\
\hline 2007 & -0.008 & -0.013 & -0.014 & $-0.030^{* *}$ & 0.018 & -0.010 \\
\hline$F$-statistics & 1.29 & 2.26 & 2.07 & 5.23 & 0.52 & 0.08 \\
\hline 2008 & 0.004 & -0.002 & -0.003 & -0.018 & 0.027 & 0.008 \\
\hline F-statistics & 0.41 & 0.06 & 0.07 & 1.90 & 1.13 & 0.06 \\
\hline 2009 & $0.022^{* * *}$ & $0.017^{*}$ & $0.021^{* *}$ & 0.011 & $0.083^{* * *}$ & $0.066^{* *}$ \\
\hline F-statistics & 11.31 & 3.73 & 4.56 & 0.74 & 10.85 & 3.91 \\
\hline 2010 & -0.006 & -0.005 & $-0.022^{* *}$ & $-0.038^{* * *}$ & 0.033 & 0.013 \\
\hline$F$-statistics & 0.49 & 2.20 & 4.94 & 8.79 & 1.72 & 0.14 \\
\hline 2011 & -0.006 & -0.000 & -0.017 & $-0.032^{* *}$ & $0.051^{*}$ & 0.020 \\
\hline$F$-statistics & 0.00 & 1.14 & 2.32 & 5.93 & 3.25 & 0.34 \\
\hline 2012 & $-0.012^{*}$ & $-0.021^{* *}$ & $-0.048^{* * *}$ & $-0.036^{* * *}$ & -0.016 & -0.043 \\
\hline$F$-statistics & 2.61 & 5.08 & 8.00 & 11.91 & 0.31 & 1.44 \\
\hline
\end{tabular}


Table 5. (Continued)

\begin{tabular}{lcccccccc}
\hline & \multicolumn{2}{c}{$\begin{array}{c}\text { Real GDP growth } \\
\text { volatility }\end{array}$} & & \multicolumn{2}{c}{$\begin{array}{c}\text { Real consumption } \\
\text { growth volatility }\end{array}$} & & \multicolumn{2}{c}{$\begin{array}{c}\text { Real investment } \\
\text { growth volatility }\end{array}$} \\
\cline { 2 - 3 } & OLS & IV & & OLS & IV & & OLS & IV \\
\hline 2013 & -0.006 & -0.015 & & $-0.023^{*}$ & $-0.042^{* * *}$ & & -0.010 & -0.041 \\
F-statistics & 0.48 & 2.16 & & 3.70 & 8.50 & & 0.11 & 1.17 \\
\hline
\end{tabular}

Notes: Only coefficients of foreign bank-related variables are reported. The numbers in parentheses are heteroscedasticity consistent standard errors. F-statistics test the hypothesis that the coefficient of Foreign Banks in that year equals zero. $*, * *$ and $* * *$ denote statistical significance at the 10 percent, 5 percent and 1 percent levels, respectively.

macroeconomic volatility remain negative and statistically significant, regardless of the model or the estimation method used. Moreover, a positive and significant coefficient is observed in 2009 for output, consumption and investments. Nevertheless, the findings suggest that foreign banks reduced the volatility of output and consumption in 2007 and during the post-crisis period (2010-2013).

Second, it can be argued that because of endogenity between growth and foreign bank presence, the Foreign Bank variable should be controlled in the first-step estimation of growth rates. Hence, we estimate our model by controlling for foreign bank assets to total assets in the first step. As evident from Table 6, our main findings do not change; the negative and significant coefficient of foreign banks on output and consumption fluctuations remains when we control for foreign banks in the first stage. We observe the amplifying role of foreign banks in all macroeconomic components in 2009 and the dampening role of these banks on consumption volatility since then.

As a third robustness check, we use the squared values of residuals from the first-step regressions as measures of unexpected changes or volatility of real GDP, consumption and investment. As evident from Table 7, the findings are very similar to those reported in Tables 2-4. The dampening effect of foreign banks on GDP and consumption volatility is found to be significant after 2009 .

To eliminate the concerns of multinational bank groups about Emerging Europe's financial stability, the Vienna Initiative was created to ensure sufficient funding for banks operating in the region. Participating countries were Bosnia and Herzegovina, Hungary, Latvia, Romania and Serbia. With the Vienna Initiative, foreign banks agreed to maintain overall exposures and recapitalize subsidiaries. Because the flow of additional capital continued to these countries during the crisis period, we exclude these countries from our sample as a last robustness check and estimate our models with the countries that did not participate in the Vienna Initiative. The results are summarized in Table 8 . We observe a significant and negative association between foreign bank presence and consumption growth volatility for 
Table 6. Estimations controlling for foreign bank presence in the first-stage

\begin{tabular}{|c|c|c|c|c|c|c|}
\hline & \multicolumn{2}{|c|}{$\begin{array}{l}\text { Real GDP growth } \\
\text { volatility }\end{array}$} & \multicolumn{2}{|c|}{$\begin{array}{l}\text { Real consumption } \\
\text { growth volatility }\end{array}$} & \multicolumn{2}{|c|}{$\begin{array}{l}\text { Real investment } \\
\text { growth volatility }\end{array}$} \\
\hline & OLS & IV & OLS & IV & OLS & IV \\
\hline \multicolumn{7}{|l|}{ Model I } \\
\hline Foreign Banks & $\begin{array}{c}-0.008^{* *} \\
(0.003)\end{array}$ & $\begin{array}{c}-0.013^{* *} \\
(0.006)\end{array}$ & $\begin{array}{c}-0.014^{* * *} \\
(0.005)\end{array}$ & $\begin{array}{c}-0.020^{* *} \\
(0.008)\end{array}$ & $\begin{array}{c}0.006 \\
(0.013)\end{array}$ & $\begin{array}{r}-0.005 \\
(0.021)\end{array}$ \\
\hline \multicolumn{7}{|l|}{ Model II } \\
\hline Foreign Banks & $\begin{array}{c}-0.013^{* * *} \\
(0.003)\end{array}$ & $\begin{array}{c}-0.018^{* * *} \\
(0.006)\end{array}$ & $\begin{array}{c}-0.018^{* * *} \\
(0.005)\end{array}$ & $\begin{array}{c}-0.022^{* * *} \\
(0.007)\end{array}$ & $\begin{array}{r}-0.009 \\
(0.014)\end{array}$ & $\begin{array}{r}-0.018 \\
(0.021)\end{array}$ \\
\hline$Y_{2007} \times$ Foreign Banks & $\begin{array}{c}0.003 \\
(0.004)\end{array}$ & $\begin{array}{c}0.006 \\
(0.006)\end{array}$ & $\begin{array}{c}0.006 \\
(0.013)\end{array}$ & $\begin{array}{c}0.004 \\
(0.014)\end{array}$ & $\begin{array}{c}0.029 \\
(0.026)\end{array}$ & $\begin{array}{c}0.020 \\
(0.024)\end{array}$ \\
\hline$Y_{2008} \times$ Foreign Banks & $\begin{array}{c}0.014^{*} \\
(0.007)\end{array}$ & $\begin{array}{c}0.015^{*} \\
(0.008)\end{array}$ & $\begin{array}{c}0.010 \\
(0.010)\end{array}$ & $\begin{array}{c}0.009 \\
(0.012)\end{array}$ & $\begin{array}{c}0.028 \\
(0.020)\end{array}$ & $\begin{array}{c}0.030 \\
(0.022)\end{array}$ \\
\hline$Y_{2009} \times$ Foreign Banks & $\begin{array}{l}0.035^{* * *} \\
(0.010)\end{array}$ & $\begin{array}{l}0.034^{* * *} \\
(0.010)\end{array}$ & $\begin{array}{l}0.038^{* * *} \\
(0.009)\end{array}$ & $\begin{array}{l}0.039^{* * *} \\
(0.012)\end{array}$ & $\begin{array}{l}0.092^{* * *} \\
(0.022)\end{array}$ & $\begin{array}{l}0.091^{* * *} \\
(0.020)\end{array}$ \\
\hline$Y_{2010} \times$ Foreign Banks & $\begin{array}{c}0.007 \\
(0.005)\end{array}$ & $\begin{array}{c}0.007 \\
(0.005)\end{array}$ & $\begin{array}{r}-0.005 \\
(0.009)\end{array}$ & $\begin{array}{r}-0.006 \\
(0.008)\end{array}$ & $\begin{array}{c}0.031 \\
(0.023)\end{array}$ & $\begin{array}{c}0.035 \\
(0.024)\end{array}$ \\
\hline$Y_{2011} \times$ Foreign Banks & $\begin{array}{c}0.009^{*} \\
(0.005)\end{array}$ & $\begin{array}{c}0.008 \\
(0.005)\end{array}$ & $\begin{array}{c}0.006 \\
(0.009)\end{array}$ & $\begin{array}{c}0.001 \\
(0.010)\end{array}$ & $\begin{array}{c}0.035 \\
(0.027)\end{array}$ & $\begin{array}{c}0.038 \\
(0.028)\end{array}$ \\
\hline$Y_{2012} \times$ Foreign Banks & $\begin{array}{c}0.000 \\
(0.003)\end{array}$ & $\begin{array}{r}-0.001 \\
(0.004)\end{array}$ & $\begin{array}{r}-0.011^{*} \\
(0.010)\end{array}$ & $\begin{array}{c}-0.015^{\star *} \\
(0.007)\end{array}$ & $\begin{array}{r}-0.007 \\
(0.016)\end{array}$ & $\begin{array}{r}-0.013 \\
(0.018)\end{array}$ \\
\hline$Y_{2013} \times$ Foreign Banks & $\begin{array}{c}0.007 \\
(0.005)\end{array}$ & $\begin{array}{c}0.006 \\
(0.007)\end{array}$ & $\begin{array}{r}-0.004 \\
(0.011)\end{array}$ & $\begin{array}{r}-0.011^{*} \\
(0.006)\end{array}$ & $\begin{array}{r}-0.006 \\
(0.015)\end{array}$ & $\begin{array}{r}-0.013 \\
(0.018)\end{array}$ \\
\hline \multicolumn{7}{|c|}{ Coefficient on Foreign Banks in years } \\
\hline 2007 & $-0.010^{*}$ & -0.011 & -0.011 & -0.018 & 0.020 & 0.003 \\
\hline F-statistics & 2.74 & 2.32 & 1.65 & 2.65 & 0.76 & 0.01 \\
\hline 2008 & 0.001 & -0.002 & -0.007 & -0.013 & 0.018 & 0.012 \\
\hline F-statistics & 0.02 & 0.07 & 0.70 & 1.25 & 0.65 & 0.18 \\
\hline 2009 & $0.022^{* * *}$ & $0.017^{* *}$ & $0.021^{* *}$ & 0.017 & $0.082^{* * *}$ & $0.073^{* *}$ \\
\hline F-statistics & 12.61 & 4.76 & 4.76 & 2.13 & 11.55 & 6.21 \\
\hline 2010 & -0.006 & -0.011 & $-0.022^{* *}$ & $-0.029^{* *}$ & 0.022 & 0.017 \\
\hline$F$-statistics & 0.95 & 2.03 & 5.68 & 6.29 & 0.82 & 0.35 \\
\hline 2011 & -0.004 & -0.010 & -0.012 & $-0.022^{*}$ & 0.026 & 0.020 \\
\hline$F$-statistics & 0.43 & 1.53 & 1.52 & 3.41 & 1.03 & 0.45 \\
\hline 2012 & $-0.013^{*}$ & $-0.019^{* *}$ & $-0.029^{* * *}$ & $-0.037^{* * *}$ & -0.016 & -0.030 \\
\hline$F$-statistics & 3.83 & 5.24 & 8.14 & 9.11 & 0.36 & 0.93 \\
\hline
\end{tabular}


Table 6. (Continued)

\begin{tabular}{lcccccccc}
\hline & \multicolumn{2}{c}{$\begin{array}{c}\text { Real GDP growth } \\
\text { volatility }\end{array}$} & & \multicolumn{2}{c}{$\begin{array}{c}\text { Real consumption } \\
\text { growth volatility }\end{array}$} & & \multicolumn{2}{c}{$\begin{array}{c}\text { Real investment } \\
\text { growth volatility }\end{array}$} \\
\cline { 2 - 3 } & OLS & IV & & OLS & IV & & OLS & IV \\
\hline 2013 & -0.006 & -0.011 & & $-0.022^{*}$ & $-0.033^{* *}$ & & -0.016 & -0.031 \\
F-statistics & 0.69 & 1.68 & & 3.78 & 6.49 & & 0.29 & 0.84 \\
\hline
\end{tabular}

Notes: Only coefficients of foreign bank-related variables are reported. The numbers in parentheses are heteroscedasticity consistent standard errors. F-statistics test the hypothesis that the coefficient of Foreign Banks in that year equals zero. $*, * *$ and $* * *$ denote statistical significance at the 10 percent, 5 percent and 1 percent levels, respectively.

Table 7. Squared residuals (alternative volatility measure)

\begin{tabular}{|c|c|c|c|c|c|c|}
\hline & \multicolumn{2}{|c|}{$\begin{array}{c}\text { Real GDP growth } \\
\text { volatility }\end{array}$} & \multicolumn{2}{|c|}{$\begin{array}{l}\text { Real consumption } \\
\text { growth volatility }\end{array}$} & \multicolumn{2}{|c|}{$\begin{array}{l}\text { Real investment } \\
\text { growth volatility }\end{array}$} \\
\hline & OLS & IV & OLS & IV & OLS & IV \\
\hline \multicolumn{7}{|l|}{ Model I } \\
\hline Foreign Banks & $\begin{array}{r}-0.042^{*} \\
(0.023)\end{array}$ & $\begin{array}{r}-0.088^{*} \\
(0.046)\end{array}$ & $\begin{array}{c}-0.104^{* *} \\
(0.052)\end{array}$ & $\begin{array}{r}-0.161^{*} \\
(0.088)\end{array}$ & $\begin{array}{c}0.125 \\
(0.350)\end{array}$ & $\begin{array}{r}-0.263 \\
(0.561)\end{array}$ \\
\hline \multicolumn{7}{|l|}{ Model II } \\
\hline Foreign Banks & $\begin{array}{l}-0.076^{* * *} \\
(0.021)\end{array}$ & $\begin{array}{l}-0.118^{* * *} \\
(0.043)\end{array}$ & $\begin{array}{l}-0.138^{* * *} \\
(0.039)\end{array}$ & $\begin{array}{c}-0.182^{* *} \\
(0.076)\end{array}$ & $\begin{array}{r}-0.189 \\
(0.341)\end{array}$ & $\begin{array}{r}-0.519 \\
(0.546)\end{array}$ \\
\hline$Y_{2007} \times$ Foreign Banks & $\begin{array}{c}0.017 \\
(0.019)\end{array}$ & $\begin{array}{c}0.029 \\
(0.028)\end{array}$ & $\begin{array}{c}0.112 \\
(0.184)\end{array}$ & $\begin{array}{c}0.092 \\
(0.192)\end{array}$ & $\begin{array}{c}0.773 \\
(0.833)\end{array}$ & $\begin{array}{c}0.515 \\
(0.697)\end{array}$ \\
\hline$Y_{2008} \times$ Foreign Banks & $\begin{array}{l}0.102^{*} \\
(0.062)\end{array}$ & $\begin{array}{c}0.121 \\
(0.074)\end{array}$ & $\begin{array}{c}0.105 \\
(0.102)\end{array}$ & $\begin{array}{c}0.114 \\
(0.131)\end{array}$ & $\begin{array}{c}0.429 \\
(0.403)\end{array}$ & $\begin{array}{c}0.443 \\
(0.448)\end{array}$ \\
\hline$Y_{2009} \times$ Foreign Banks & $\begin{array}{l}0.276^{* * *} \\
(0.088)\end{array}$ & $\begin{array}{l}0.264^{* * *} \\
(0.089)\end{array}$ & $\begin{array}{l}0.348^{* * *} \\
(0.128)\end{array}$ & $\begin{array}{l}0.346^{* * *} \\
(0.133)\end{array}$ & $\begin{array}{l}1.848^{* * *} \\
(0.484)\end{array}$ & $\begin{array}{l}1.731^{* * *} \\
(0.428)\end{array}$ \\
\hline$Y_{2010} \times$ Foreign Banks & $\begin{array}{c}0.027 \\
(0.023)\end{array}$ & $\begin{array}{c}0.027 \\
(0.029)\end{array}$ & $\begin{array}{r}-0.073 \\
(0.058)\end{array}$ & $\begin{array}{r}-0.091 \\
(0.075)\end{array}$ & $\begin{array}{c}0.711 \\
(0.550)\end{array}$ & $\begin{array}{c}0.783 \\
(0.565)\end{array}$ \\
\hline$Y_{2011} \times$ Foreign Banks & $\begin{array}{c}0.035 \\
(0.025)\end{array}$ & $\begin{array}{c}0.037 \\
(0.030)\end{array}$ & $\begin{array}{c}0.031 \\
(0.096)\end{array}$ & $\begin{array}{r}-0.018 \\
(0.096)\end{array}$ & $\begin{array}{c}0.825 \\
(0.656)\end{array}$ & $\begin{array}{c}0.867 \\
(0.682)\end{array}$ \\
\hline$Y_{2012} \times$ Foreign Banks & $\begin{array}{c}-0.007 \\
(0.017)\end{array}$ & $\begin{array}{r}-0.008 \\
(0.023)\end{array}$ & $\begin{array}{c}-0.105^{* *} \\
(0.051)\end{array}$ & $\begin{array}{c}-0.132^{* *} \\
(0.067)\end{array}$ & $\begin{array}{l}-0.197 \\
(0.273)\end{array}$ & $\begin{array}{r}-0.281 \\
(0.300)\end{array}$ \\
\hline$Y_{2013} \times$ Foreign Banks & $\begin{array}{c}0.023 \\
(0.027)\end{array}$ & $\begin{array}{c}0.034 \\
(0.045)\end{array}$ & $\begin{array}{r}-0.083 \\
(0.059)\end{array}$ & $\begin{array}{r}-0.129^{*} \\
(0.067)\end{array}$ & $\begin{array}{r}-0.242 \\
(0.240)\end{array}$ & $\begin{array}{r}-0.324 \\
(0.292)\end{array}$ \\
\hline
\end{tabular}


Table 7. (Continued)

\begin{tabular}{|c|c|c|c|c|c|c|}
\hline & \multicolumn{2}{|c|}{$\begin{array}{l}\text { Real GDP growth } \\
\text { volatility }\end{array}$} & \multicolumn{2}{|c|}{$\begin{array}{l}\text { Real consumption } \\
\text { growth volatility }\end{array}$} & \multicolumn{2}{|c|}{$\begin{array}{l}\text { Real investment } \\
\text { growth volatility }\end{array}$} \\
\hline & OLS & IV & OLS & IV & OLS & IV \\
\hline \multicolumn{7}{|c|}{ Coefficient on Foreign Banks in years } \\
\hline 2007 & -0.059 & -0.088 & -0.026 & -0.090 & 0.584 & -0.004 \\
\hline F-statistics & 1.78 & 2.47 & 0.07 & 0.54 & 0.92 & 0.00 \\
\hline 2008 & 0.026 & 0.003 & -0.033 & -0.068 & 0.239 & -0.077 \\
\hline$F$-statistics & 0.37 & 0.00 & 0.12 & 0.31 & 0.16 & 0.01 \\
\hline 2009 & $0.200^{* * *}$ & $0.146^{* *}$ & $0.210^{* *}$ & 0.164 & $1.658^{* * *}$ & 1.212 \\
\hline$F$-statistics & 18.68 & 6.64 & 4.28 & 1.78 & 6.75 & 2.42 \\
\hline 2010 & -0.049 & -0.090 & $-0.210^{* *}$ & $-0.273^{* *}$ & 0.521 & 0.264 \\
\hline$F$-statistics & 1.13 & 2.54 & 4.27 & 4.92 & 0.66 & 0.12 \\
\hline 2011 & -0.041 & -0.081 & -0.107 & -0.199 & 0.635 & 0.348 \\
\hline$F$-statistics & 0.70 & 1.93 & 1.01 & 2.50 & 0.90 & 0.19 \\
\hline 2012 & -0.083 & $-0.126^{* *}$ & $-0.243^{* *}$ & $-0.313^{* *}$ & -0.386 & -0.801 \\
\hline$F$-statistics & 2.66 & 4.30 & 4.78 & 5.64 & 0.31 & 0.92 \\
\hline 2013 & -0.053 & -0.084 & $-0.221^{*}$ & $-0.310^{* *}$ & -0.432 & -0.844 \\
\hline$F$-statistics & 0.93 & 1.66 & 3.35 & 4.84 & 0.32 & 0.90 \\
\hline
\end{tabular}

Notes: Only coefficients of foreign bank-related variables are reported. The numbers in parentheses are heteroscedasticity consistent standard errors. F-statistics test the hypothesis that the coefficient of Foreign Banks in that year equals zero. *,** and $* * *$ denote statistical significance at the 10 percent, 5 percent and 1 percent levels, respectively.

Table 8. Estimations excluding countries participating in the Vienna initiative

\begin{tabular}{|c|c|c|c|c|c|c|}
\hline & \multicolumn{2}{|c|}{$\begin{array}{l}\text { Real GDP growth } \\
\text { volatility }\end{array}$} & \multicolumn{2}{|c|}{$\begin{array}{l}\text { Real consumption } \\
\text { growth volatility }\end{array}$} & \multicolumn{2}{|c|}{$\begin{array}{l}\text { Real investment } \\
\text { growth volatility }\end{array}$} \\
\hline & OLS & IV & OLS & IV & OLS & IV \\
\hline \multicolumn{7}{|l|}{ Model I } \\
\hline Foreign Banks & $\begin{array}{r}-0.006^{*} \\
(0.004)\end{array}$ & $\begin{array}{r}-0.006 \\
(0.006)\end{array}$ & $\begin{array}{c}-0.014^{* *} \\
(0.006)\end{array}$ & $\begin{array}{l}-0.022^{* * *} \\
(0.008)\end{array}$ & $\begin{array}{c}0.002 \\
(0.013)\end{array}$ & $\begin{array}{c}0.006 \\
(0.020)\end{array}$ \\
\hline \multicolumn{7}{|l|}{ Model II } \\
\hline Foreign Banks & $\begin{array}{l}-0.012^{* * *} \\
(0.003)\end{array}$ & $\begin{array}{r}-0.010^{*} \\
(0.005)\end{array}$ & $\begin{array}{l}-0.021^{* * *} \\
(0.005)\end{array}$ & $\begin{array}{l}-0.025^{* * *} \\
(0.007)\end{array}$ & $\begin{array}{r}-0.014 \\
(0.014)\end{array}$ & $\begin{array}{r}-0.005 \\
(0.020)\end{array}$ \\
\hline$Y_{2007} \times$ Foreign Banks & $\begin{array}{c}0.005 \\
(0.005)\end{array}$ & $\begin{array}{c}0.006 \\
(0.006)\end{array}$ & $\begin{array}{c}0.016 \\
(0.018)\end{array}$ & $\begin{array}{c}0.014 \\
(0.019)\end{array}$ & $\begin{array}{c}0.008 \\
(0.016)\end{array}$ & $\begin{array}{c}0.006 \\
(0.018)\end{array}$ \\
\hline
\end{tabular}


Table 8. (Continued)

\begin{tabular}{|c|c|c|c|c|c|c|}
\hline & \multicolumn{2}{|c|}{$\begin{array}{l}\text { Real GDP growth } \\
\text { volatility }\end{array}$} & \multicolumn{2}{|c|}{$\begin{array}{l}\text { Real consumption } \\
\text { growth volatility }\end{array}$} & \multicolumn{2}{|c|}{$\begin{array}{l}\text { Real investment } \\
\text { growth volatility }\end{array}$} \\
\hline & OLS & IV & OLS & IV & OLS & IV \\
\hline$Y_{2008} \times$ Foreign Banks & $\begin{array}{c}0.012 \\
(0.008)\end{array}$ & $\begin{array}{c}0.015 \\
(0.011)\end{array}$ & $\begin{array}{c}0.016 \\
(0.012)\end{array}$ & $\begin{array}{c}0.016 \\
(0.015)\end{array}$ & $\begin{array}{c}0.038 \\
(0.023)\end{array}$ & $\begin{array}{c}0.042 \\
(0.026)\end{array}$ \\
\hline$Y_{2009} \times$ Foreign Banks & $\begin{array}{l}0.043^{* * *} \\
(0.011)\end{array}$ & $\begin{array}{l}0.045^{* * *} \\
(0.010)\end{array}$ & $\begin{array}{l}0.048^{* * *} \\
(0.014)\end{array}$ & $\begin{array}{l}0.052^{* * *} \\
(0.014)\end{array}$ & $\begin{array}{l}0.099^{* * *} \\
(0.021)\end{array}$ & $\begin{array}{l}0.097^{* * *} \\
(0.018)\end{array}$ \\
\hline$Y_{2010} \times$ Foreign Banks & $\begin{array}{c}0.009^{*} \\
(0.005)\end{array}$ & $\begin{array}{c}0.008 \\
(0.005)\end{array}$ & $\begin{array}{r}-0.002 \\
(0.007)\end{array}$ & $\begin{array}{r}-0.003 \\
(0.008)\end{array}$ & $\begin{array}{c}0.049 \\
(0.032)\end{array}$ & $\begin{array}{c}0.046 \\
(0.034)\end{array}$ \\
\hline$Y_{2011} \times$ Foreign Banks & $\begin{array}{l}0.012^{* *} \\
(0.006)\end{array}$ & $\begin{array}{r}0.012^{*} \\
(0.007)\end{array}$ & $\begin{array}{c}0.015 \\
(0.012)\end{array}$ & $\begin{array}{c}0.011 \\
(0.012)\end{array}$ & $\begin{array}{c}0.056^{*} \\
(0.033)\end{array}$ & $\begin{array}{c}0.060^{*} \\
(0.035)\end{array}$ \\
\hline$Y_{2012} \times$ Foreign Banks & $\begin{array}{c}0.003 \\
(0.004)\end{array}$ & $\begin{array}{c}0.002 \\
(0.005)\end{array}$ & $\begin{array}{r}-0.004 \\
(0.007)\end{array}$ & $\begin{array}{r}-0.005 \\
(0.008)\end{array}$ & $\begin{array}{c}0.019 \\
(0.020)\end{array}$ & $\begin{array}{c}0.014 \\
(0.022)\end{array}$ \\
\hline$Y_{2013} \times$ Foreign Banks & $\begin{array}{l}0.012^{* *} \\
(0.006)\end{array}$ & $\begin{array}{c}0.012 \\
(0.008)\end{array}$ & $\begin{array}{c}0.000 \\
(0.008)\end{array}$ & $\begin{array}{r}-0.004 \\
(0.008)\end{array}$ & $\begin{array}{c}0.007 \\
(0.019)\end{array}$ & $\begin{array}{r}-0.002 \\
(0.021)\end{array}$ \\
\hline \multicolumn{7}{|c|}{ Coefficient on Foreign Banks in Years } \\
\hline 2007 & -0.006 & -0.004 & -0.005 & -0.012 & -0.006 & 0.000 \\
\hline F-statistics & 0.82 & 0.22 & 0.19 & 0.86 & 0.05 & 0.00 \\
\hline 2008 & 0.000 & 0.005 & -0.005 & -0.009 & 0.023 & 0.037 \\
\hline F-statistics & 0.00 & 0.31 & 0.22 & 0.54 & 0.93 & 1.47 \\
\hline 2009 & $0.032^{* * *}$ & $0.035^{* * *}$ & $0.027^{* *}$ & $0.027^{* *}$ & $0.085^{* * *}$ & $0.092^{* * *}$ \\
\hline F-statistics & 17.90 & 15.17 & 5.90 & 4.09 & 10.56 & 8.57 \\
\hline 2010 & -0.003 & -0.002 & $-0.022^{* *}$ & $-0.029^{* *}$ & 0.034 & 0.041 \\
\hline$F$-statistics & 0.15 & 0.07 & 3.97 & 4.82 & 1.70 & 1.68 \\
\hline 2011 & 0.001 & 0.002 & -0.006 & -0.014 & 0.041 & $0.055^{*}$ \\
\hline$F$-statistics & 0.01 & 0.05 & 0.23 & 1.10 & 2.16 & 2.92 \\
\hline 2012 & -0.009 & -0.008 & $-0.025^{* *}$ & $-0.030^{* *}$ & 0.005 & 0.009 \\
\hline$F$-statistics & 1.11 & 0.73 & 4.11 & 4.99 & 0.03 & 0.07 \\
\hline 2013 & 0.001 & 0.001 & -0.021 & $-0.029^{*}$ & -0.007 & -0.008 \\
\hline$F$-statistics & 0.00 & 0.02 & 2.22 & 3.63 & 0.05 & 0.04 \\
\hline
\end{tabular}

Notes: Only coefficients of foreign bank-related variables are reported. The numbers in parentheses are heteroscedasticity consistent standard errors. F-statistics test the hypothesis that the coefficient of Foreign Banks in that year equals zero. ${ }^{*}, * *$ and $* * *$ denote statistical significance at the 10 percent, 5 percent and 1 percent levels, respectively. 
the whole sample period, regardless of the model or method used in the estimations. The coefficients of interaction variables between foreign banks and year dummy variables after 2009 are found to be positive and significant in explaining output volatility but the coefficients of Foreign Banks in the post-crisis period are insignificant. A much greater magnitude of the coefficients of Foreign Banks in 2009 suggests that the Vienna Initiative benefited countries in terms of reducing the impact of the global shock during the crisis and thus aided the recovery periods.

\section{Conclusion}

In this paper, we examine the association between foreign bank presence and economic volatility using a sample of 20 Emerging European countries over the period 1998-2013. In particular, we focused on the global crisis period of 2008/ 2009 to assess whether foreign banks have any effect on output, consumption and investment growth volatilities. Our findings suggest that the increased presence of foreign banks in the domestic banking system can be considered a stabilizing force in Emerging European countries in normal periods. Although foreign banks resisted pulling out of the region in the global crisis, we found that they amplified the fluctuation of GDP, consumption and investment growth rates in 2009. However, immediately after the crisis period they especially helped consumption smoothing.

We also find that greater financial development is associated with lower investment growth volatility, indicating the importance of promoting financial access in Emerging Europe. One way to enhance bank lending services is to provide them through foreign banks. However, it seems that at this stage, these banks fail to stabilize investment volatility. Considering our findings that foreign banks that participated in the Vienna Initiative further mitigated output and consumption volatility, and considering the findings by De Haas et al. (2015) that foreign banks are stable lenders in the region, policies to promote financial access and foreign ownership may help mitigate macroeconomic fluctuations of possible shocks.

As a further study, one can examine cross-border lending to the region. Although cross-border lending and lending by local brick-and-mortar subsidiaries and branches are two different forms of lending, most emerging economies suffered from the sharp slowdown of both flows during the recent global crisis. Hence, an analysis of the impact of cross-border bank lending on macroeconomic fluctuations will improve our understanding of different forms of financial integration.

\section{References}

Agénor, P. R. (2003). 'Benefits and costs of international financial integration: Theory and facts', World Economy, 26(8), pp. 1089-1118. 
Agénor, P. R. (2013). 'International financial integration: Benefits, costs and policy challenges', in Baker, H. K. and Riddick, L. A. (eds.), International Finance: A Survey, Oxford, NY: Oxford University Press, pp. 110-137.

Aghion, P., Banerjee, A. and Piketty, T. (1999). 'Dualism and macroeconomic volatility', Quarterly Journal of Economics, 114(4), pp. 1359-1397.

Aghion, P., Bacchetta, P. and Banerjee, A. (2004). 'Financial development and the instability of open economies', Journal of Monetary Economics, 51(5), pp. 1077-1106.

Aghion, P., Bacchetta, P., Rancière, R. and Rogoff, K. (2009). 'Exchange rate volatility and productivity growth: The role of financial development', Journal of Monetary Economics, 55(4), pp. 494-513.

Allen, F., Beck, T., Carletti, E., Lane, P. R., Schoenmaker, D. and Wagner, W. (2011). Cross-Border Banking in Europe: Implications for Financial Stability and Macroeconomic Policies, London: CEPR.

Althammer, W. and Haselmann, R. (2011). 'Explaining foreign bank entrance in emerging markets', Journal of Comparative Economics, 39(4), pp. 486-498.

Bacchetta, P. and Caminal, R. (2000). 'Do capital market imperfections exacerbate output fluctuations?' European Economic Review, 44(3), pp. 449-468.

Barth, J. R., Caprio, G. and Levine, R. (2006). Rethinking Bank Regulation and Supervision: Till Angels Govern, Cambridge: Cambridge University Press.

Beck, T. and Laeven, L. (2006). 'Institution building and growth in transitional economies', Journal of Economic Growth, 11(2), pp. 157-186.

Beck, T., Lundberg, M. and Majnoni, G. (2006). 'Financial intermediary development and growth volatility: Do intermediaries dampen or magnify shocks?' Journal of International Money and Finance, 25(7), pp. 1146-1167.

Bekaert, G., Harvey, C. R. and Lundblad, C. (2005). 'Does financial liberalization spur growth?' Journal of Financial Economics, 77(1), pp. 3-55.

Berglöf, E., Korniyenko, Y., Plekhanov, A. and Zettelmeyer, J. (2010). 'Understanding the crisis in Emerging Europe', Public Policy Review, 6(6), pp. 985-1008.

Bonin, J. P. and Schnabel, I. (2011). 'The great transformation: From government-owned to foreign-controlled banking sectors', Economics of Transition, 19(3), pp. 397-405.

Bonin, J. P., Hasan, I. and Wachtel, P. (2005a). 'Bank performance, efficiency and ownership in transition countries', Journal of Banking and Finance, 29(1), pp. 31-53.

Bonin, J. P., Hasan, I. and Wachtel, P. (2005b). 'Privatization matters: Bank efficiency in transition countries', Journal of Banking and Finance, 29(8-9), pp. 2155-2178.

Buch, C. M. (1997). 'Opening up for foreign banks: How Central and Eastern Europe can bene-

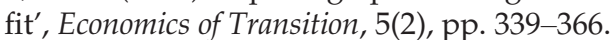

Buch, C. M., Carstensen, K. and Schertler, A. (2010). 'Macroeconomic shocks and banks' foreign assets', Journal of Money, Credit and Banking, 42(1), pp. 171-188.

Caballero, R. J. and Krishnamurthy, A. (2001). 'International and domestic collateral constraints in a model of emerging market crises', Journal of Monetary Economics, 48(3), pp. 513-548.

Caprio, G. and Honohan, P. (2002). 'Banking policy and macroeconomic stability: An exploration', Policy Research Working Papers No. 2856, Washington, DC: The World Bank.

Cardim de Carvalho, F. J. (2000). 'New competitive strategies of foreign banks in large emerging economies: The case of Brazil', Banca Nazionale del Lavoro Quarterly Review, 213, pp. 135-169.

Cetorelli, N. and Goldberg, L. S. (2011). 'Global banks and international shock transmission: Evidence from the crisis', IMF Economic Review, 59(1), pp. 41-76. 
Claessens, S. and van Horen, N. (2014). 'Foreign banks: Trends, impact and financial stability', Journal of Money, Credit and Banking, 46(s1), pp. 295-326.

Claessens, S., Demirgüç-Kunt, A. and Huizinga, H. (2001). 'How does foreign entry affect domestic banking markets?' Journal of Banking and Finance, 25(5), pp. 891-911.

Clarke, G. R. G., Cull, R. and Martínez Pería, M. S. (2006). 'Foreign bank participation and access to credit across firms in developing countries', Journal of Comparative Economics, 34 (4), pp. 774-795.

Crystal, J. S., Dages, B. G. and Goldberg, L. S. (2002). 'Has foreign bank entry led to sounder banks in Latin America?', Current Issues in Economics and Finance. Federal Reserve Bank of New York, 8(1), pp. 1-6.

Cull, R. and Martínez Pería, M. S. (2013). 'Bank ownership and lending patterns during the 2008-2009 financial crisis: Evidence from Latin America and Eastern Europe', Journal of Banking and Finance, 37(12), pp. 4861-4878.

Dabla-Norris, E. and Srivisal, N. (2013). 'Revisiting the link between finance and macroeconomic volatility', IMF Working Paper No. 13/29, Washington, DC: IMF.

De Haas, R. and van Lelyveld, I. (2006). 'Foreign banks and credit stability in Central and Eastern Europe: A panel data analysis', Journal of Banking and Finance, 30(7), pp. 19271952.

De Haas, R. and van Lelyveld, I. (2014). 'Multinational banks and the global financial crisis: Weathering the perfect storm?' Journal of Money, Credit, and Banking, 46(1), pp. 333-364.

De Haas, R., Korniyenko, Y., Pivovarsky, A. and Tsankova, T. (2015). 'Taming the herd? Foreign banks, the Vienna Initiative and crisis transmission', Journal of Financial Intermediation, 24(3), pp. 325-355.

Detragiache, E. and Gupta, P. (2006). 'Foreign banks in emerging market crises: Evidence from Malaysia', Journal of Financial Stability, 2(3), pp. 217-242.

Detragiache, E., Tressel, T. and Gupta, P. (2008). 'Foreign banks in poor countries: Theory and evidence', Journal of Finance, 63(5), pp. 2123-2160.

Focarelli, D. and Pozzolo, A. F. (2005). 'Where do banks expand abroad? An empirical analysis', The Journal of Business, 78(6), pp. 2435-2464.

Fries, S. and Taci, A. (2005). 'Cost efficiency of banks in transition: Evidence from 289 banks in 15 post-communist countries', Journal of Banking and Finance, 29(1), pp. 55-81.

Galindo, A.J., Izquierdo, A. and Rojas-Suarez, L. (2010). 'Financial integration and foreign banks in Latin America: How do they impact the transmission of external financial shocks?', in Jeon, B. N. and Olivero, M. P. (eds.), Global Banking, Financial Markets and Crises (International Finance Review, Volume 14) pp. 305-339

Giannetti, M. and Ongena, S. (2009). 'Financial integration and firm performance: Evidence from foreign bank entry in emerging markets', Review of Finance, 13(2), pp. 181-223.

Goldberg, L. S. (2007). 'Financial sector FDI and host countries: New and old lessons', Economic Policy Review, Federal Reserve Bank of New York, 13(1), pp. 1-17.

Goldberg, L. S., Dages, B. G. and Kinney, D. (2000). 'Foreign and domestic bank participation in emerging markets: Lessons from Mexico and Argentina', NBER Working Papers No. 7714, Cambridge, MA: National Bureau of Economic Research.

Grittersova, J. (2014). 'Transfer of reputation: Multinational banks and perceived creditworthiness of transition countries', Review of International Political Economy, 21(4), pp. 878-912. 
Havrylchyk, O. and Jurzyk, E. (2011). 'Inherited or earned? Performance of foreign banks in Central and Eastern Europe', Journal of Banking and Finance, 35(5), pp. 1291-1302.

Klomp, J. and De Haan, J. (2009). 'Political institutions and economic volatility', European Journal of Political Economy, 25(3), pp. 311-326.

Levine, R. (1996). 'Foreign banks, financial development and economic growth', in Barfield, C. E. (ed.), International Financial Markets: Harmonization versus Competition, Washington, DC: AEI Press, pp. 224-254.

Mathieson, D. J. and Roldos, J. (2001). 'Foreign banks in emerging markets', in Litan, R. E., Masson, P. and Pomerleano, M. (eds.), Open Doors: Foreign Participation in Financial Systems in Developing Countries, Washington, DC: Brookings Institution Press, pp. 15-55.

Mihaljek, D. (2011). 'Domestic bank intermediation in emerging market economies during the crisis: Locally owned versus foreign-owned banks', in Bank for International Settlements (ed.), The Global Crisis and Financial Intermediation in Emerging Market Economies, Bank for International Settlements, 54, pp. 31-48.

Morgan, D. P. and Strahan, P. E. (2004). 'Foreign bank entry and business volatility: Evidence from U.S. states and other countries', in Ahumada, A. and Fuentes, J. R. (eds), Banking Market Structure and Monetary Policy, Santiago, Chile: Central Bank of Chile, pp. 241-269.

Morgan, D. P., Rime, B. and Strahan, P. E. (2004). 'Bank integration and state business cycles', Quarterly Journal of Economics, 119(4), pp. 1555-1584.

Naaborg, I., Scholtens, B., De Haan, J., Bol, H. and de Haas, R. (2004). 'How important are foreign banks in the financial development of European transition countries?' Journal of Emerging Market Finance, 3(2), pp. 99-123.

Peek, J. and Rosengren, E. S. (2000). 'Implications of the globalization of the banking sector: The Latin American experience', New England Economic Review, September/October, pp. 45-62.

Poghosyan, T. and Poghosyan, A. (2010). 'Foreign bank entry, bank efficiency and market power in Central and Eastern European Countries', Economics of Transition, 18(3), pp. 571-598.

Prasad, E. S. (1998). 'International trade and the business cycle', The Economic Journal, 109 (458), pp. 588-606.

Prasad, E., Rajan, R. G. and Subramanian, A. (2007). 'Foreign capital and economic growth', Brookings Papers on Economic Activity, 38(1), pp. 153-230.

Shleifer, A. and Vishny, R. W. (2010). 'Unstable banking', Journal of Financial Economics, 97(3), pp. 306-318.

Sims, C. A. (1980). 'Macroeconomics and reality', Econometrica, 48(1), pp. 1-48. 


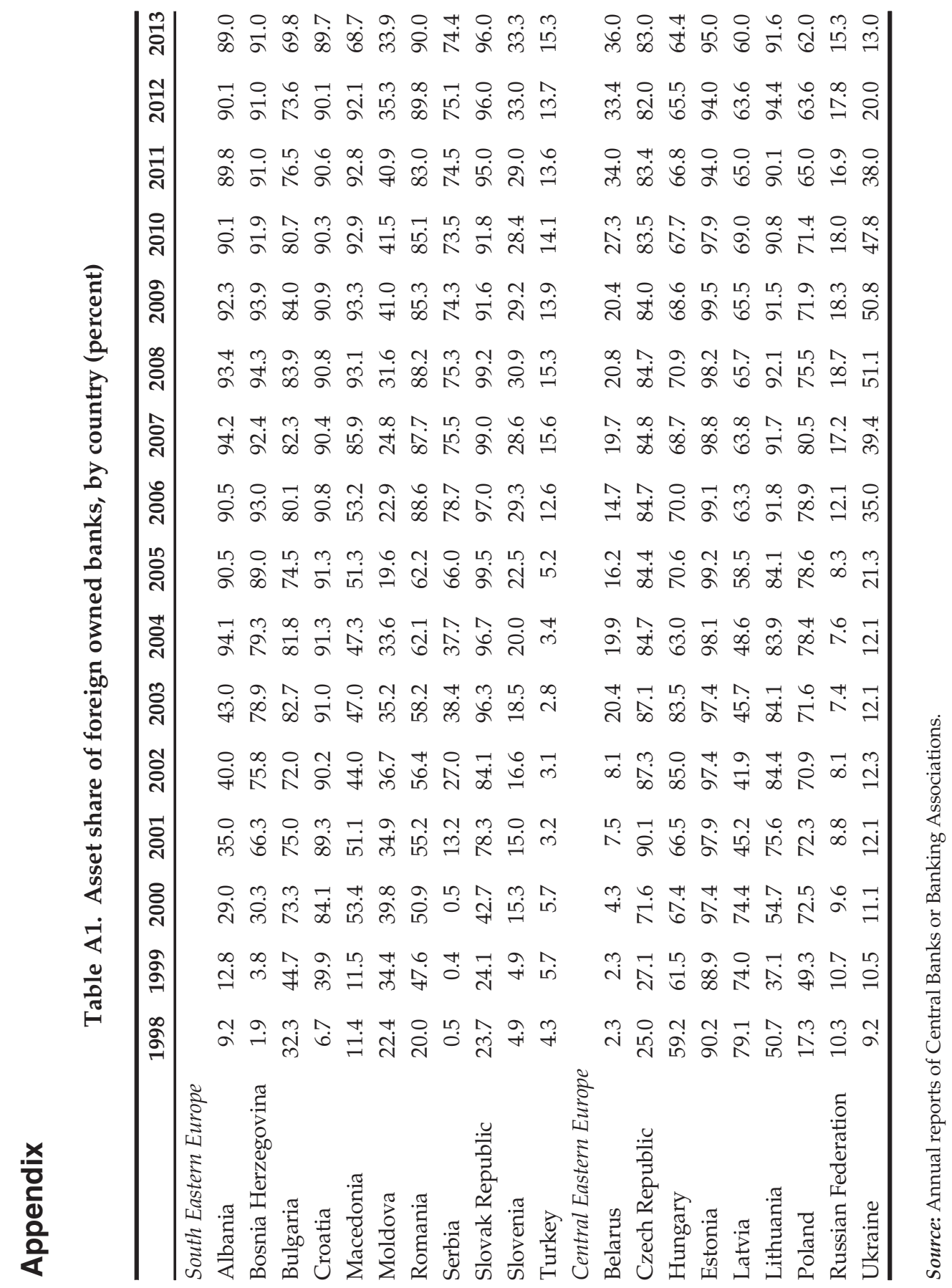

(C) 2016 The Authors Economics of Transition (c) 2016 The European Bank for Reconstruction and Development 
Table A2. First stage growth panel regressions

\begin{tabular}{|c|c|c|c|}
\hline & \multicolumn{3}{|c|}{ Dependent variable: Real growth rate in } \\
\hline & GDP & Consumption & Investment \\
\hline \multirow[t]{2}{*}{ Intercept } & 80.149 & 12.367 & 157.396 \\
\hline & $(98.524)$ & $(143.482)$ & $(360.338)$ \\
\hline \multirow[t]{2}{*}{ Trade Openness } & $0.053^{* * *}$ & 0.010 & $0.137^{* *}$ \\
\hline & $(0.018)$ & $(0.026)$ & $(0.065)$ \\
\hline \multirow[t]{2}{*}{ FDI to GDP } & -0.030 & -0.024 & -0.072 \\
\hline & $(0.039)$ & $(0.057)$ & $(0.145)$ \\
\hline \multirow[t]{2}{*}{ Unemployment Rate } & $-0.149^{*}$ & $-0.345^{* * *}$ & -0.422 \\
\hline & $(0.082)$ & $(0.115)$ & $(0.287)$ \\
\hline \multirow[t]{2}{*}{ Growth in Population } & $-0.219^{* *}$ & -0.017 & -1.104 \\
\hline & $(0.507)$ & $(0.738)$ & $(1.863)$ \\
\hline \multirow[t]{2}{*}{ Years in Secondary School } & $12.303^{* * *}$ & 7.426 & 18.001 \\
\hline & $(4.439)$ & $(6.495)$ & $(16.264)$ \\
\hline \multirow[t]{2}{*}{ External Debt to GDP } & -0.016 & -0.014 & -0.062 \\
\hline & $(0.012)$ & $(0.017)$ & $(0.042)$ \\
\hline \multirow[t]{2}{*}{ Government to GDP } & $-0.318^{* * *}$ & $-0.278^{*}$ & -0.231 \\
\hline & $(0.106)$ & $(0.154)$ & $(0.388)$ \\
\hline \multirow{2}{*}{$\log ($ Expected Life $)$} & -23.025 & -2.632 & -117.300 \\
\hline & $(23.561)$ & $(34.300)$ & $(210.790)$ \\
\hline \multirow[t]{2}{*}{$\log (1+$ Inflation $)$} & $-3.353^{*}$ & -3.793 & $-26.599^{* * *}$ \\
\hline & $(1.967)$ & $(2.813)$ & $(7.153)$ \\
\hline \multirow{2}{*}{$\log (\text { Growth })_{-1}$} & 0.048 & 0.031 & 0.029 \\
\hline & $(0.066)$ & $(0.062)$ & $(0.064)$ \\
\hline Adjusted $R^{2}$ & 0.589 & 0.498 & 0.409 \\
\hline F-statistics & $10.86^{* * *}$ & $7.83^{* * *}$ & $5.77^{* * *}$ \\
\hline$N$ & 304 & 304 & 304 \\
\hline
\end{tabular}

Notes: $*, * *$ and $* * *$ denote statistical significance at the 10 percent, 5 percent and 1 percent levels, respectively. The coefficients of country and year fixed effects are not reported to save space.

For the GDP, consumption and investment growth models, lagged levels of real GDP, consumption and investment are used, respectively. The numbers in parentheses are standard errors. 


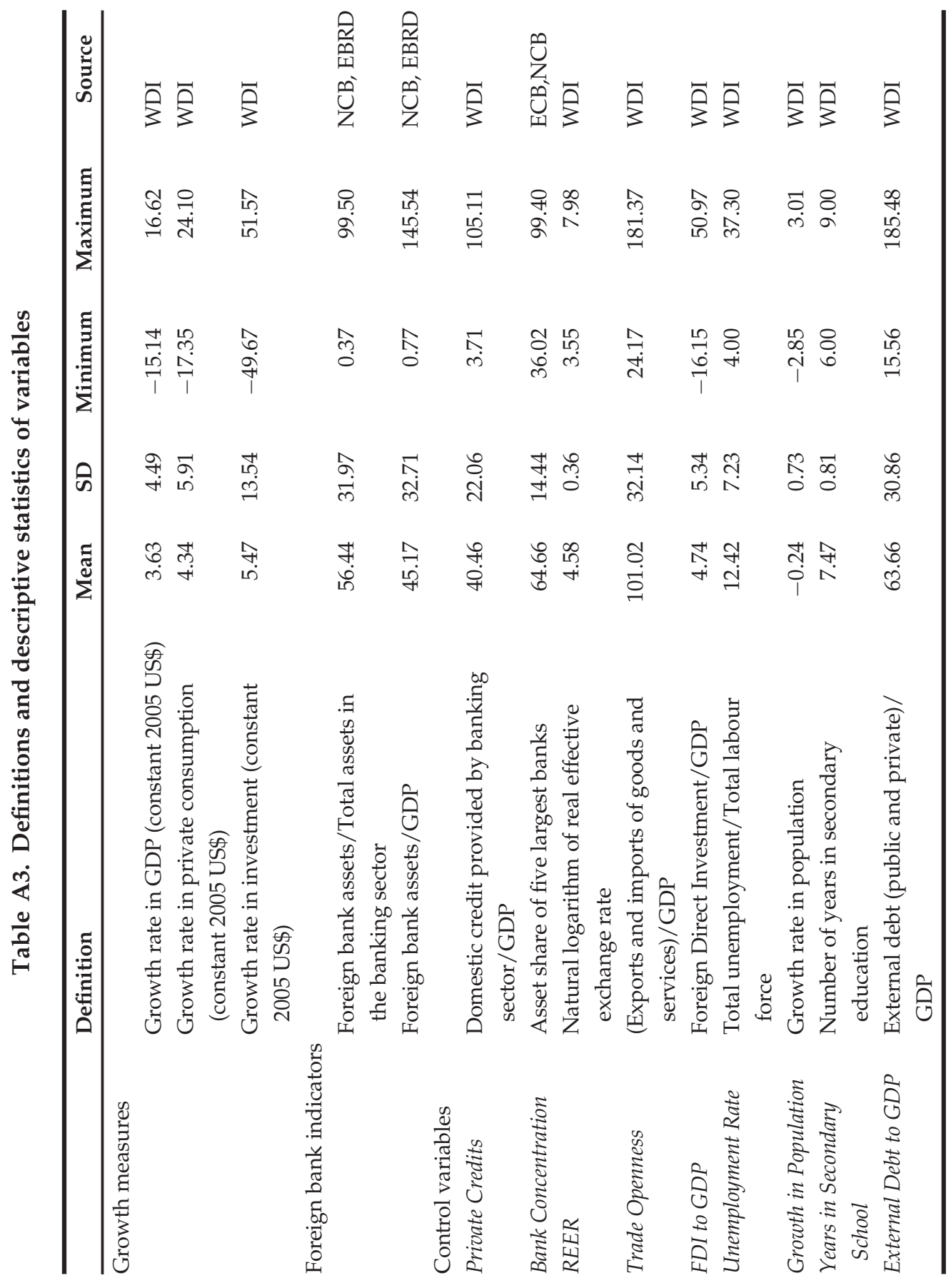

(c) 2016 The Authors 


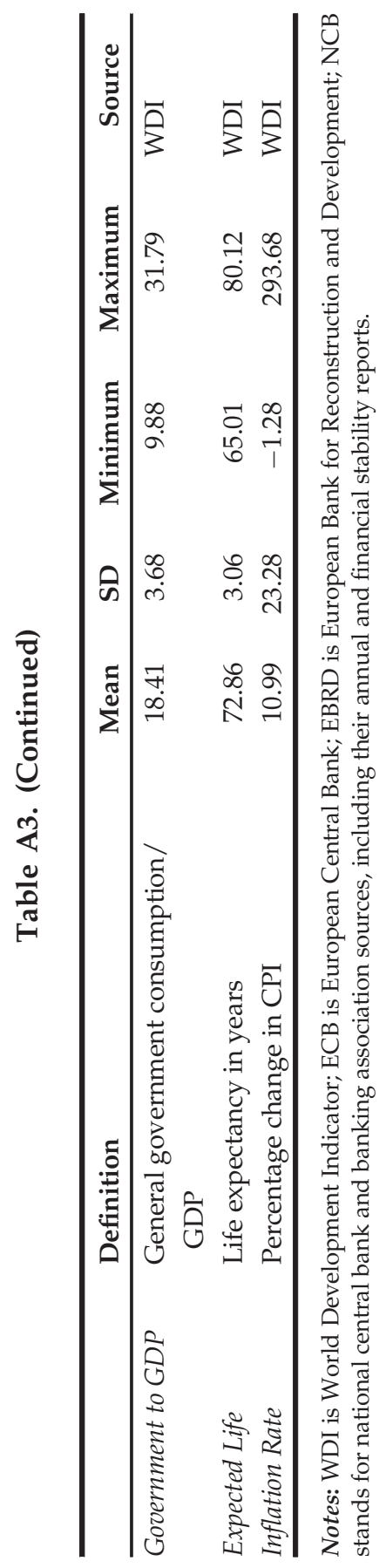

(c) 2016 The Authors

Economics of Transition (C) 2016 The European Bank for Reconstruction and Development 